*ak RMIS View/Frint Document Cover Sheet tow

This document was retrieved from the Documentation and Records Manaqement (DRM) ISEARCH System. It is intended for Information only and may not be the most recent or updated version. Contact a Document Service Center (see Hanford Info for locations) if you need additional retrieval information.

Accession \#: D196012473

Document \#: SD-W030-ATR-007

Title/Desc:

ACCEPTANCE TEST REPORT BACKUP POWER SYSTEM

Pages: 46 


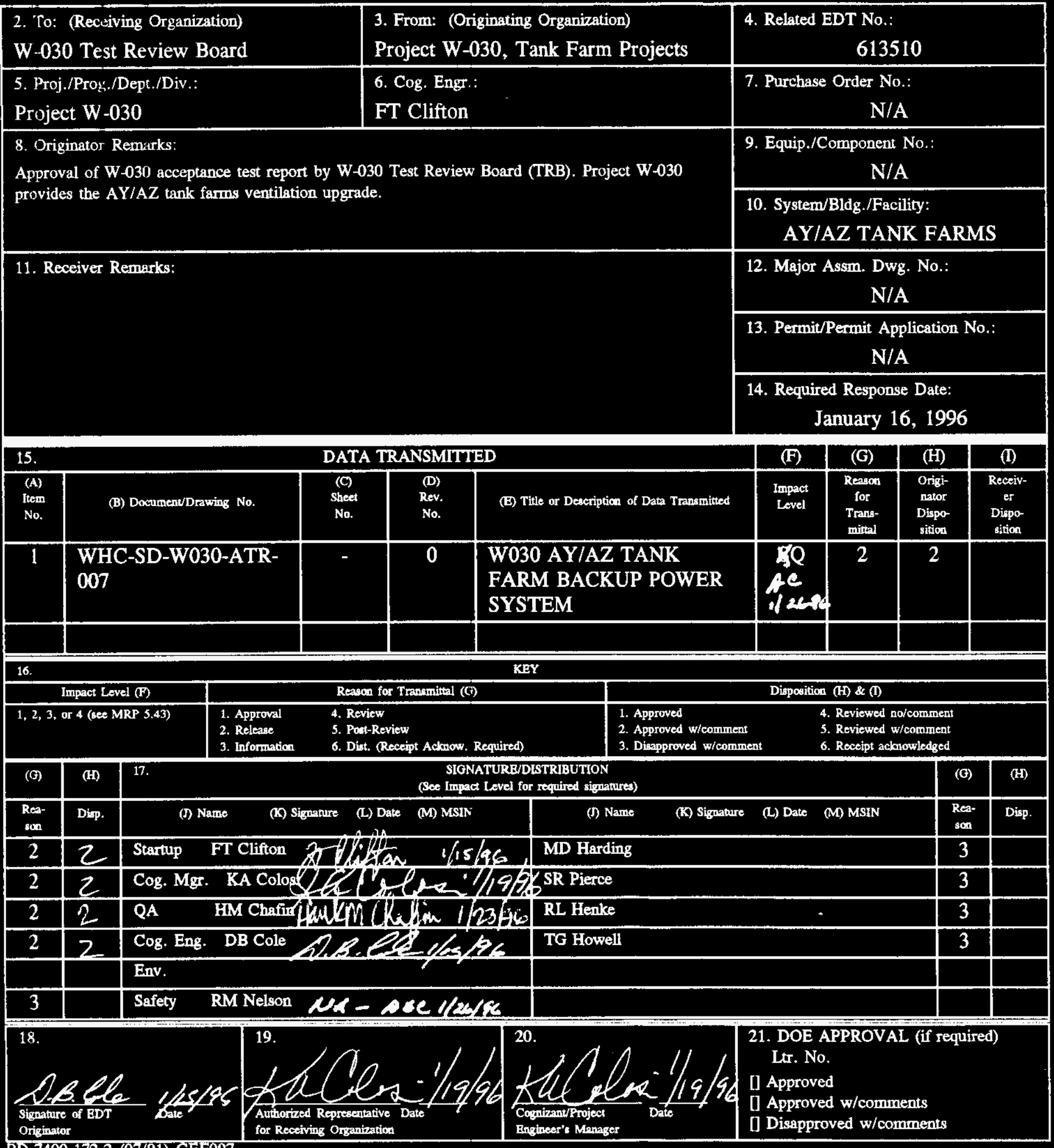

BD-7400-172-2 (07/91) GEF097 


\section{ACCEPTANCE TEST REPORT, BACKUP POWER SYSTEM}

\section{DB Cole}

Westinghouse Hanford Company, Richland, WA 99352

U.S. Department of Energy Contract DE-AC06-87RL10930

$\begin{array}{lll}\text { EDT /ECN: } & 614734 & \text { UC: } 2030 \\ \text { Org Code: } & 8 K 240 & \text { Charge Code: NK201 } \\ \text { B\&R Code: } & \text { EW3130010 } & \text { Total Pages: } \$ 2\end{array}$

Key Words: TEST, POWER, VENTILATION, BACKUP, ELECTRICAL

Abstract: Acceptance Test Report for construction functional testing of Project $W-030$ Backup Power System. Project $W-030$ provides a ventilation upgrade for the four Aging Waste Facility tanks. Backup power includes a single $125 \mathrm{KW}$ diesel generator, three 10-kva uninterruptible power supply units, and all necessary control.

TRADEMARK DISCLAIMER. Reference herein to any specific combrcial product, process, or service by trade name, trademark, manufacturer, or otherwise, does not necessarily constitute or imply its endorsenent, recomendation, or favoring by the United States Government or any agency thereof or its contractors or subcontractors.

Printed in the United States of Anerica. To obtain copies of this document, contact: WHC/BCS Document Control Services, P.0. Box 1970, Mailstop H6-08, RifhlandML 92352, Phone (509) 372-2420; Fax (509) 376-4989.
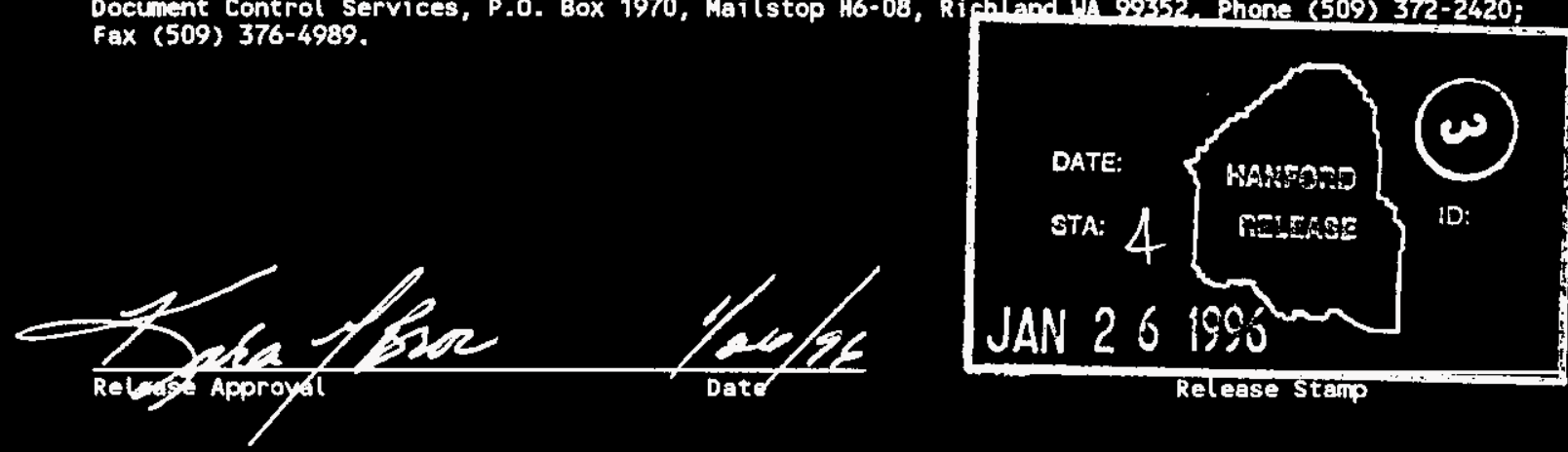

Approved for Public Release 


\section{TEST TITLE BACK-UP POUER SYSTEM}

LOCATION 200E, Butldings 241-A7-701 and 241-A7-702

PROJECT NUMBER $\mathrm{H}-030$ WORK ORDER

CR1132

PROJECT TITLE TANK FARM VENTILATION UPGRADE

Prepared By

ICF Kaiser Hanford Company

Richland, Washington

For the U.S. Department of Energy

Contract DE-AC06-93RL12359

PROCEDURE APPROVAL

ICF KAISER HANFORO COMPANY (ICF KH)

$m<$ alefarder

Author

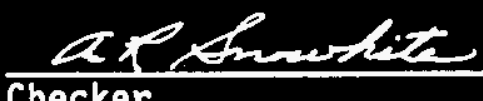

checker

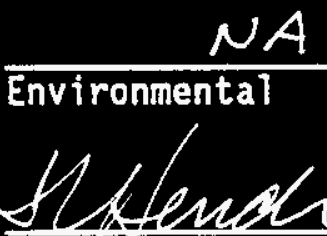

Project Management

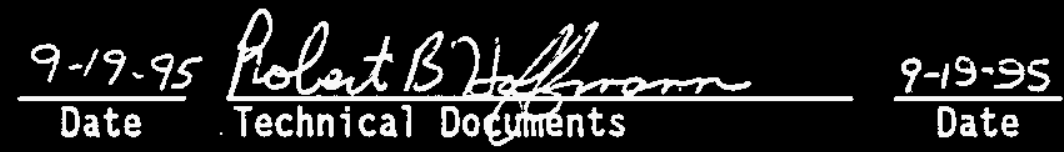
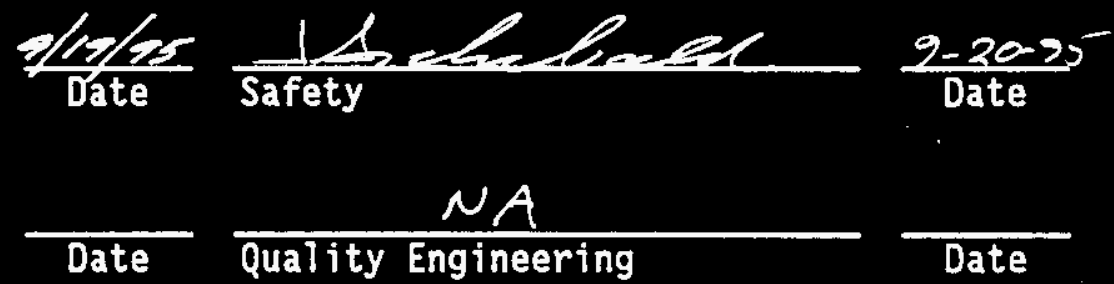

$\frac{N A}{\text { Quality Engineering }}$

Date

WESTINGHOUSE HANFORD COMPANY (WHC)

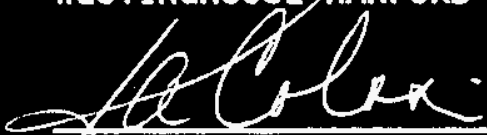

Project Management

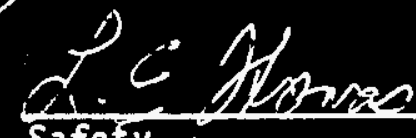

Safety

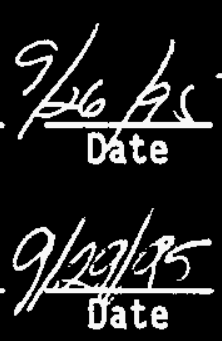
$\frac{9 / 2195}{\text { Dite }}$ 


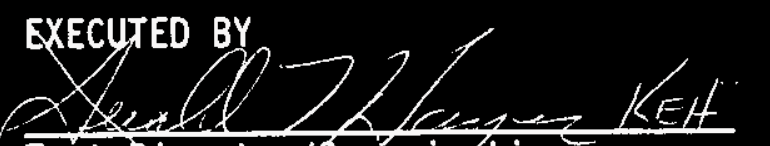

Test Director/Organization

$\frac{2^{\prime} / 2195}{\text { Date }}$

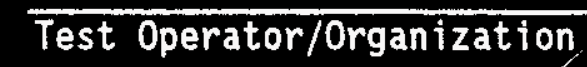

Date

Recorder/Organization

Date

WITNESSES

Witness/Organization
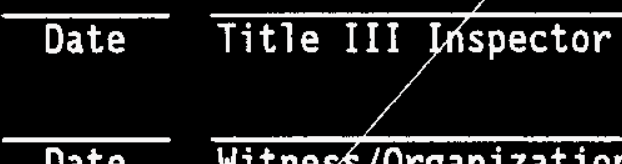

Date

Witness/Organization

Date Witness/Organization

Date

\section{A-E APPROVAL}

ICF Kaiser Hanford Company (ICF KH)

Without

exceptions

With exceptions

resolved

With exceptions

outstanding

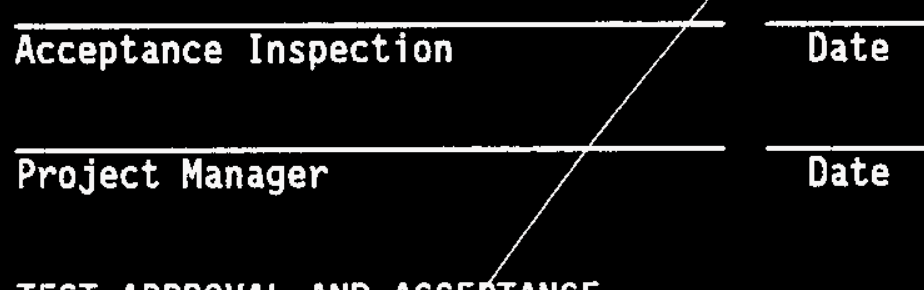

TEST APPROVAL AND ACCEPTANCE

Westinghouse Hanford Company (WHC)

Without

exceptions

With exceptions resolved

With exceptions

outstanding

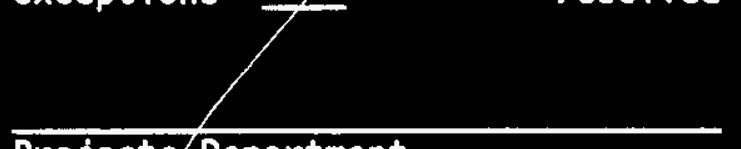

Projects Department

Date Quality Assurance

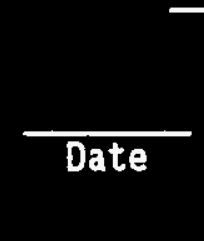

Safethy

Date Operations

$$
\begin{aligned}
& \partial g y t 12(2) / 95 \\
& \text { selete extra paje. }
\end{aligned}
$$




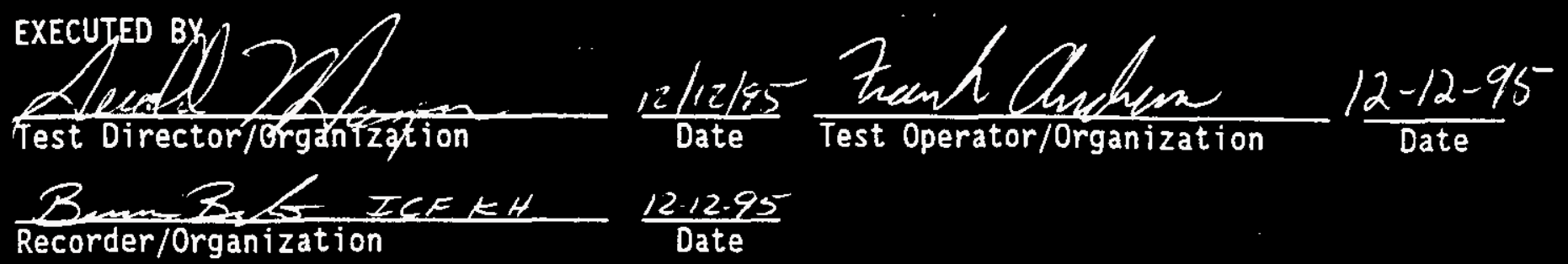

WITNESSES

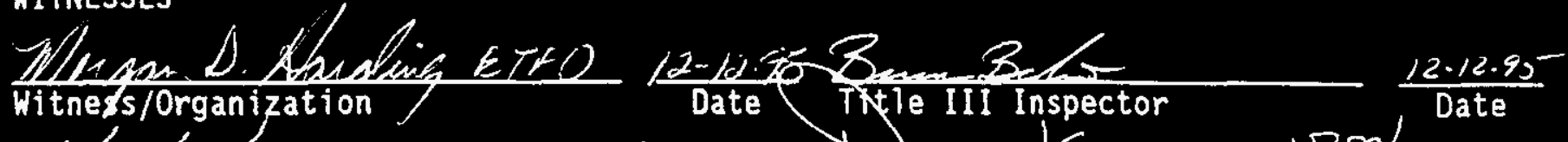

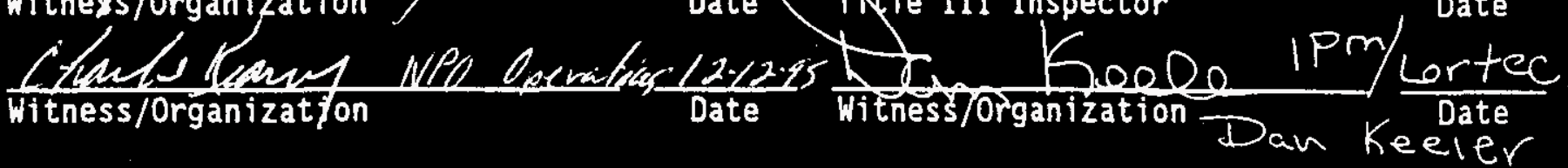

\section{A-E APPROVAL}

ICF Kaiser Hanford Company (ICF KH)

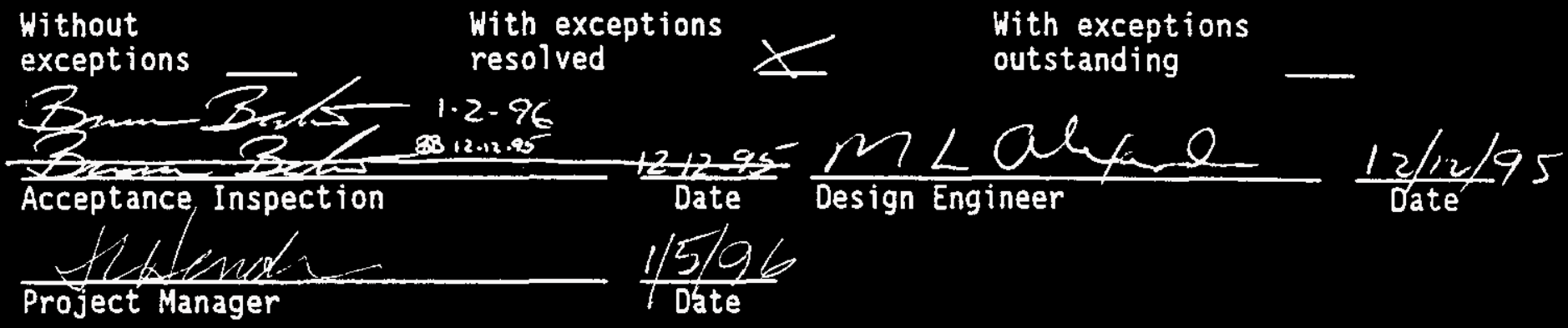

TEST APPROVAL AND ACCEPTANCE

Westinghouse Hanford Company (WHC)

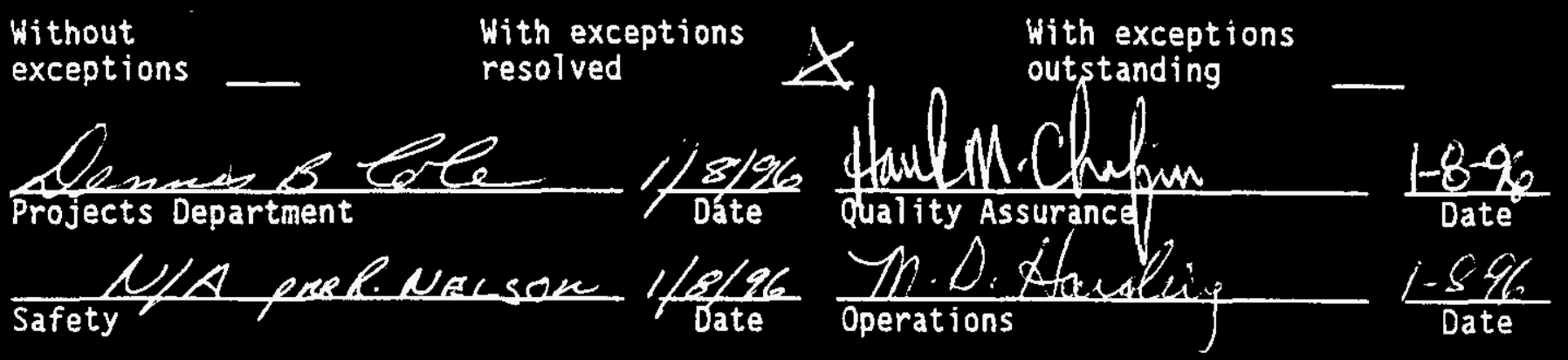


TITLE/PROCEDURE APPROVAL

EXECUTION AND TEST APPROVAL

TABLE OF CONTENTS

1 PURPOSE

REFERENCES

CHANGE CONTROL

7 PREREQUISITES, EQUIPMENT/INSTRUMENTS, AND ABBREVIATIONS

NOTE: At completion of test, enter pages added during performance of test to this Table of Contents.

$$
\begin{aligned}
& T E-001 \\
& T E-002 \\
& T E-003 \\
& T E-004 \\
& T E-005 \\
& T E-006 \\
& T E-007
\end{aligned}
$$


This Acceptance Test Procedure (ATP) has been prepared to demonstrate that the Electrical Back-Up Power System consisting of one (1) diesel generator, three (3) automatic transfer switches (ATS), and three (3) uninterruptible power supply systems (UPS) functions as required by project criteria.

\section{REFERENCES}

\section{$2.1 \quad$ DRAWINGS}

H-2-131353, Sh 1, Rev 0 Electrical One-Line Diagram

H-2-131353, Sh 2, Rev 0 Electrical One-Line Diagram

H-2-131368, Sh 1, Rev 0 Electrical Elem/Conn Diagram Diesel Generator System

\subsection{SPECIFICATIONS}

$$
\begin{aligned}
& W-030-C 2, \operatorname{Rev} 0 \\
& W-030-P 11, \operatorname{Rev} 0 \\
& W-030-P 17, \text { Rev } 0 \\
& W-030-P 17
\end{aligned}
$$$$
\text { W-030-P11 }
$$

Construction Specification Tank Farm Ventilation Upgrade

Procurement Specification for Diesel Generator System

Procurement Specification for Uninterruptible Power Supply System

Vendor Information -- Operations and Maintenance Manual for Model IBP+10 Uninterruptible Power Systen (UPS)

Vendor Information -- Service Manual EMCP II (SENR58098-01 Apri1 94)

Vendor Information -- Instruction Manual Automatic Transfer Switch 40 through 3000 Amps ZTSH Series (Zenith Controls 43R-1000B Rev 8/94)

\subsection{OTHER}

NONE

2.4 ENGINEERING CHANGE NOTICES (ECN)

Prior to final test approval, enter ECNs written against this ATP. $E C N-W-030-175$ 
3.1 GENERAL

Each company or organization participating in this ATP will designate personnel to assume the responsibilities and duties as defined herein for their respective roles. The designees shall become familiar with this ATP and the systems involved to the extent that they can perform their assigned duties.

3.2 WHC PROJECT ENGINEER

3.2.1 Designates a Test Director.

3.2.2 Coordinates testing with the Facility Manager.

3.2.3 Acts as liaison between the participants in acceptance testing.

3.2.4 Distributes the approved testing schedule before start of testing.

3.2.5 Schedules and conducts a pretest kickoff meeting with test participants when necessary.

3.2.6 Notifies the persons supporting the test 2 days before the start of testing.

3.2.7 Schedules a dry run when necessary. .

3.2.8 Notifies concerned parties when a change is made in the testing schedule.

3.2.9 Signs Execution and Test Approval page when test is approved and accepted.

3.2.10 Takes necessary action to clear exceptions to the test.

3.2.11 Signs Exception Form when exception has been resolved.

3.2.12 Provides a distribution list for the approved and accepted ATP(ATR).

\subsection{TEST DIRECTOR}

3.3.1 Coordinates and directs acceptance testing.

3.3.2 Confirms that field testing and inspection of the system or portion of the system to be tested has been completed.

3.3.3 Stops any test which, in his or her judgment, may cause damage to the system until the problem has been resolved.

3.3.4 After verifying there is no adverse impact, may alter the sequence in which systems or subsystems are tested.

3.3.5 Ensures that required environmental conditions are maintained.

3.3.6 If a test is to be suspended for a period of time, ensures that the system is left in a safe mode. 
3.3.7 Before restarting suspended test, reverifies the test prerequisites.

3.3.8 Initiates ECNs to document required changes to the ATP.

3.3.9 Reviews recorded data, discrepancies, and exceptions.

3.3.10 Obtains information or changes necessary to clear or resolve objections during the performance of the test.

3.3.11 Signs Execution and Test Approval page when test has been performed.

3.3.12 Signs Exception Form when exception has been resolved.

3.3.13 Obtains required signatures on the ATP Master prior to reproduction and distribution.

3.4 WITNESSES (Provided by Participating Organizations. One witness shall be a Title III acceptance inspector.)

3.4.1 Witness the tests.

3.4.2 Review results of testing.

3.4.3 Assist the Test Director when requested.

3.4.4 Sign Execution and Test Approval page when test has been performed.

3.4.5 Sign Exception Form when exception has been resolved.

3.5 RECOROER (Provided by ICF KH)

3.5.1 Prepares a Field copy from the ATP Master.

3.5.2 Records names of all designated personnel on Field copy of ATP prior to start of testing.

3.5.3 Records test instrument identification numbers and calibration expiration dates, as required.

3.5.4 Initials and dates every test step on the Field copy as it is completed next to the step number or on a data sheet, when provided. Records test data. On data sheets where there is not room for both the initial and date, date may be entered at botton of column.

3.5.5 Records objections and exceptions on an Exception form. Uses additional Exception forms as needed. Notifies the Test Director at time the objection is made.

3.5.6 Signs Execution and Test Approval page when test has been performed.

3.5.7 After test is finished, assigns alpha numeric page numbers to added data sheets and Exception forms. Records page numbers in the Table of Contents. 
3.5.8 Transfers Field copy entries for each step to the Master in ink or type, signs, and dates. Transmits the completed Master to the Test Director for approval signature routing. Transmits the field copy to Construction Document Control for inclusion in the official project file.

3.5.9 Signs Exception Form when exception has been resolved and transmits to Test Director.

3.6 TEST OPERATOR

3.6.1 Performs test under direction of the Test Director.

3.6.2 Provides labor, equipment, and test instruments required for performing tests which have not been designated as being provided by others.

3.6.3 Requests in writing from the Test Director those services, materials, or equipment that have been designated as being supplied by others.

3.6.4 Confirms that all equipment required for performing test will be available at the start of testing.

3.6.5 Signs the Execution and Test Approval page.

3.7 A-E ACCEPTANCE INSPECTION, DESIGN ENGINEER, AND PROJECT MANAGER

3.7.1 Evaluate results.

3.7.2 Sign for A-E Approval on Execution and Test Approval page.

4 CHANGE CONTROL

Required changes to this ATP must be processed on ECNs in accordance with company procedures. If a need for change is discovered in the course of running the test, the test shall be stopped until the ECN is approved. However, this does not prevent the running of another portion of the test unaffected by the change.

$5 \quad$ EXECUTION

5.1 OCCUPATIONAL SAFETY AND HEALTH

Individuals shall carry out their assigned work in a safe manner to protect themselves and others from undue hazards and to prevent damage to property and environment. Facility line managers shall assure the safety of activities within their areas to prevent injury, property damage, or interruption of operation. Performance of test activities shall always include safety and health aspects. 


\subsection{PERFORMANCE}

5.2.1 Conduct testing in accordance with ICF KH Procedure CON 3.5

(Performance and Recording of Acceptance Test Procedures).

5.2.2 Perform test following the steps and requirements of this procedure.

\section{EXCEPTIONS}

6.1 GENERAL

Exceptions to the required test results are sequentially numbered and recorded on individual Exception forms. This enables case-by-case resolution and approval of each exception.

Errors/exceptions in the ATP itself shall NOT be processed as test exceptions (see Section 4 CHANGE CONTROL).

\subsection{RECORDING}

6.2.1 Number each exception sequentially as it occurs and record it on an Exception Form (KEH-428), sample appended.

6.2.2 Enter name and organization of objecting party for each exception.

6.2.3 Enter planned action to resolve each exception when such determination is made.

\subsection{RETEST/RESOLUTION}

Record the action taken to resolve each exception. Action taken may not be the same as planned action.

6.3.1 When action taken results in an acceptable retest, sign and date Retest Execution and Acceptance section of the Exception Form.

6.3.2 When action taken does not involve an acceptable retest, strike out the Retest Execution and Acceptance section of the Exception Form.

\subsection{APPROVAL AND ACCEPTANCE}

The customer provides final approval and acceptance of exceptions by checking one of the following on Exception Form:

6.4.1 Retest Approved and Accepted: Applicable when Retest Execution and Acceptance section is completed.

6.4.2 Exception Accepted-As-Is: Requires detailed explanation.

6.4.3 Other: Requires detailed explanation.

The customer signs and dates the Exception Form and obtains other customer internal approvals, if required. 


\subsection{DISTRIBUTION}

A copy of the approved Exception Form is distributed to each participant. The signed original is attached to the ATP Master.

7 PREREQUISITES, EQUIPMENT/INSTRUMENTS, AND ABBREVIATIONS

7.1 PREREQUISITES

The following conditions shall exist at start of testing for that portion of the system being tested.

7.1.1 Back-up power system has been inspected for compliance with construction documents.

7.1.2 Reference documents (including this ATP) have been verified for correct revision number and outstanding ECNs.

7.1.3 A Prejob Safety Analysis has been prepared and a Prejob Safety Meeting has been conducted.

7.1.4 Test instruments have a valid calibration stamp attached. Test instrument identification numbers and calibration expiration dates have been recorded in Para 7.2 .

7.1.5 Record nameplate data of the diesel generator, ATS 1, ATS 2, UPS 1, UPS 2 and UPS 3.

7.1.6 Power (480 V, $3 \mathrm{PH}$ ) is available from the unit substation transformer to Standby Panelboard No. 1 and Standby Panelboard No. 2.

7.1.7 Voice communications are available as required.

\subsection{EQUI PMENT/INSTRUMENTS}

Supplied by Test Operator unless otherwise noted.

7.2.1 Vol tohmmeters (VOM): $0-600$ volts, $0-10,000$ ohms

Instrument No. $\frac{101920}{61140684}$ Expiration Date $\frac{12-8.96}{11.2 .96}$

7.2.2 Ammeters: 0-50 amperes

Instrument No. 312450 Expiration Date 12.8 .96

7.2.3 Shorting Jumpers with ON-OFF switch: 12 inch lead length.

7.2.4 Coolant Tester -50 to $+50{ }^{\circ} \mathrm{F}$ 7.2.5 Phase Rotation metor 7.3 ABBREVIATIONS

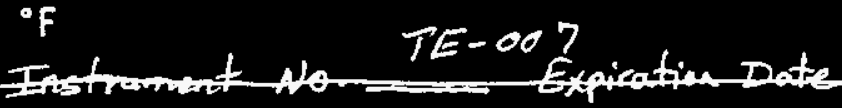

ECN Engineering Change Notice

RWP Radiation Work Permit 
SWP Special Work Procedure

ATS Automatic Transfer Switch

UPS Uninterruptible Power Supply/System

7.4 PREPARATION

The 12/11/5; 7.4.1 Verify all prerequisites of Para 7.1 have been met.

Ialutas 7.4.2 Notify Building Manager if applicable.

Notify personnel working in building(s). State whether evacuation is required.

NOTE: Keep appropriate personne 1 informed as to test status. 


\subsection{DIESEL GENERATOR}

To ensure the diesel generator will operate as intended.

$\operatorname{mex} 121201208.1 .1$

$3 m_{12 / 4 / 2} 8.1 .2$

$\operatorname{sen} 12 / 1 / 558.1 .3$

$\tan 121 \cdot \lg 58.1 .4$

$\operatorname{Ime}_{1}=/ 2 / 5=8.1 .5$

$\ln 2 / 4 / 2-8.1 .6$

$\sin 2 / 4 / 5-8.1 .6 .1$

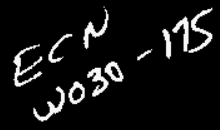

Ianedula 8.1 .7

$\operatorname{tin} 12 / 11658.1 .8$

20 dints $=8.1 .9$

$\sin 2 x_{4125} 8.1 .10$

Tam adutes 8.1.11

Tensaluer 8.1.11.1

amizles-8.1.12
Verify engine coolant level is within 2 inches from top of filler neck.

Verify, with coolant tester, the coolant freeze protection level is at $-10^{\circ} \mathrm{F}$ or below.

Verify engine crankcase oil level, using dipstick on left side of engine, is between the add and full knurled area on the dipstick.

Verify fuel level in 300-gallon fuel tank is at least $3 / 4$ full.

Manually UNLOCK and OPERATE the fuel priming pump, located on right side of engine, until fuel pressure registers on fuel pressure gauge. Push the plunger in and tighten by hand.

Verify proper electrolyte level in both starting batteries.

Verify voltage level of starting batteries, on EMCP II control panf 1 , exceeds $24 V$ dc and the Low Battery Voltage indicating 1 ight is not ILLUMINATED. If dc voltage is low, battertes-will have to be charged, GO TO Steps 10.3.16.1 through 10.3.16.4 except use temporary power for the $120 \mathrm{~V}$ ac input power to the battery charger.

Verify that there are no visible fuel, oil or coolant leaks on and around engine.

Verify all generator circuit breakers (3) are OPEN and load bank switches are OFF.

Verify engine control switch is in the OFF position.

Verify displays and lights on EMCP II control panel ILLUMINATE when the lamp test button is depressed.

Turn engine control switch to the MANUAL START position and verify engine STARTS.

Allow engine to smooth out to rated speed.

Verify the following parameters are within the range specified or adjust as required to place parameters in range:

Upper Display (Push Phase Select Key): Record indicated voltage and frequency.

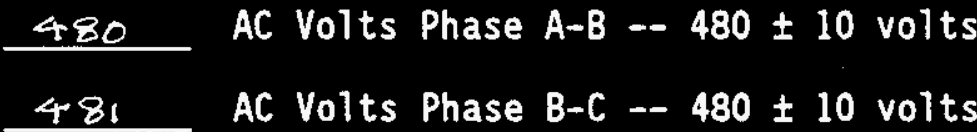


480 AC Volts Phase C-A -- $480 \pm 10$ volts

Lo Frequency $--60 \pm .5 \mathrm{~Hz}$

Lower Display (Automatic Scroll Dỉsplay):

1800 Engine RPM -- $1800 \pm 50$ RPM

81 Engine 011 Pressure -- $50 \pm 30$ psi

$\operatorname{Ian} 12 / u 1958.1 .12 .1$

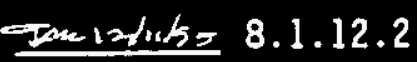

$\operatorname{Tan} 12 / 4 / 258.1 .12 .3$
Verify fuel pressure is in the Normal range.

Verify there are no unusual noises or vibrations.

Allow engine to run for approximately 5 minutes. Verify there are no faults indicated on the Generator Set Control display panel. Turn engine control switch to the OFF position and verify engine stops.

The following step will view and verify setpoints associated with important generator set conditions. Access to setpoints (P01-P21) will be from the Generator Set Control (GSC) display panel.

$12 / 4 / 5=8.1 .13$

Timalutar 8.1.13.1

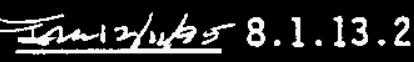

Tomede- 8.1 .13 .3

smiz/ty 8.1 .13 .4

Smiz/u/af 8.1.13.5

Implatg- 8.1.13.6

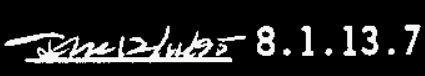

Tancester 8.1 .13 .8

Emix/w/s. 8.1 .13 .9

trancluse 8.1 .13 .10

Tanclutes 8.1.13.11

Dinstu/gs 8.1.13.12

Thenelutes-8.1.13.13
Press the SERVICE MODE key on the keypad of the GSC. The "SERV" indicator on the upper display will be flashing. Press SCROLL UP key to where "OP2" is showing on the lower display. Press SELECT key, "P01". followed with the setpoint value will be showing. Press SCRÓLL UP or SCROLL DOWN to access the other setpoint values. See EMCP II service manual for description of setpoints.

Verify "P01" setpoint is 0 .

Verify "P02" setpoint is 0 .

Verify "P03" setpoint is 0 .

Verify "P04" setpoint is 0 .

Verify "P05" setpoint is 1 .

Verify "P06" setpoint is 0.

Verify "p07" setpoint is 0 .

Verify "P08" setpoint is 0 .

Verify "pog" setpoint is 156 teeth.

Verify "P10" setpoint is $2120 \mathrm{rpm}$.

Verify "P11" setpoint is $400 \mathrm{rpm}$.

Verify "P12" setpoint is $1130 \mathrm{rpm}$.

Verify "P13" setpoint is 12 psi. 
CM12/uls 8.1.13.14 Verify "P14" setpoint is 10 psi.

Im $12 / \% / 95$ 8.1.13.15 Verify "P15" setpoint is $225^{\circ} \mathrm{F}$.

Fen $12 / 11 / 95$ 8.1.13.16 Verify "P16" setpoint is $70^{\circ} \mathrm{F}$.

Eerify "P17" setpoint is 90 seconds.

8.1.13.18 Verify "P18" setpoint is 10 seconds.

Pmiz/do5 8.1.13.19 Verify "P19" setpoint is 5 minutes.

Impluses 8.1.13.20 Verify "P20" setpoint is 700 volts.

Jmla/ulas 8.1.13.21 Verify "P21" setpoint is 300 amperes.

Thender 8.1.13.22 Press EXIT key twice to return display screen to normal.

The following steps (8.1.14 through 8.1.16) will verify that the EMCP' II control panel operates correctly when a fault occurs with engine overspeed, low oil pressure, or high coolant temperature. The password is required to access the option window to verify each fault.

\subsubsection{Overspeed Verification}

Tav121.55 8.1.14.1

Turn engine control switch to the MANUAL START position and run engine at rated speed.

$2412 / 4195-1.14 .2$

Press SERVICE MODE key. Press Scrol] Up key 2 times. Verify "OP3" is showing on lower display.

Jan $12 / 4 / 658.1 .14 .3$

Press the SELECT key, verify "PE----" is showing.

$\tan 12 /$ ulas 8.1 .14 .4

Press the SELECT key, verify "PE-----" with the first dash flashing is showing.

antulas 8.1 .14 .5

Press the SCROLL RIGHT key, verify "PE1----" with the second dash flashing is showing.

$=12 / 4 / 558.1 .14 .6$

Press the SCROLL DOWN key, verify "PE13---" with the third dash flashing is showing.

200124658.1 .14 .7

Press the SCROLL UP key, verify "PE132--" with the fourth dash flashing is showing.

$\sin 12 / 4-8.1 .14 .8$

Press the SCROLL DOWN key, verify "PE1323-" with the fifth dash flashing is showing.

$=2014658.14 .9$

Press the SCROLL RIGHT key, verify "PE13231" with all digits not flashing is showing.

$\cos 12 / 462-8.1 .14 .10$

Press ENTER key, verify "PE PASS" is showing.

Sin 12 fulaz 8.1.14.11 Press EXIT key, verify "OP1" is showing. 
gmentedes 8.1 .14 .12

ay $12 / 01558.1 .14 .13$

$\sin 12 / 1958.1 .14 .14$

$5 \mathrm{~m}(2 / 4 / 958.1 .14 .15$

$\sigma_{12 / 4 / g} 8.1 .14 .16$

entalulgr-8.1.14.17

8.1 .15

12.15te-1.1

and $1215 .-8.1 .15 .2$

Sentales 8.1.15.3

$2 \sin 12 / 12 / 258.1 .15 .4$

$\operatorname{man}_{2} / 2 / 1 / 9,8.1 .15 .5$

Wunt/4/55 8.1.15.6

8.1 .16

enatyle- 8.1.16.1

Ins $2 / 4 h-8.1 .16 .2$

$\tan _{12 / 462} 8.1 .16 .3$
Press the SCROLL UP key eight times, verify "OPg" is showing on the lower display.

Press the SELECT key. Verify the P10 setpoint value for engine overspeed of "2120" is showing on the upper display. Verify "SC1" followed with the present engine speed value is showing on the lower display.

Press the SELECT key. Verify the setpoint value "2120" is flashing on the upper display.

Press the SCROLL DOWN key to decrease the setpoint value (10 rpm with each press) that is flashing on the upper display until the setpoint value decreases past the present engine speed value that is showing on the lower display.

Verify engine shuts down and that the shutdown indicator for overspeed is flashing.

RETURN engine control switch to OFF position.

Low 0 il Pressure Verification

REPEAT Steps 8.1.14.1 through 8.1.14.13.

Press the SCROLL UP key one time. Verify the P13 setpoint value for low oil pressure of "12" is showing on the upper display. Verify "SC2" followed with the present oil pressure value is showing on the lower display.

Press the SELECT key. Verify the setpoint value "12" is flashing on the upper display.

Press the SCROLL UP key to increase the setpoint value (5 psi with each press) that is flashing on the upper display until the setpoint value increases past the present oil pressure value that is showing on the lower display.

Verify engine shuts down and that the shutdown indicator for low oil pressure is flashing.

RETURN engine control switch to OFF position.

High Water Temperature

REPEAT Steps 8.1.14.1 through 8.1.14.13.

Press the SCROLL UP key two times. Verify the P15 setpoint value for high water temperature of $225^{\circ} \mathrm{F}$ is showing on the upper

display. Verify "SC3" followed with the present coolant water temperature value is showing on the lower display.

Press the SELECT key. Verify the setpoint value $225^{\circ} \mathrm{F}$ is flashing on the upper display. 
M 12/ulas 8.1.16.4

miz/us/as 8.1 .16 .5

Tantalutar 8.1.16.6

$2 \sin 12 / 425.1 .17$

Finzidns 8.1 .18

antelulas 8.1.18.1

$\operatorname{Tan} 12 / 4258.1 .18 .2$

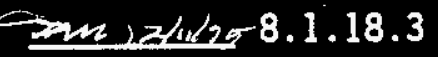

sectes. 8.1 .18 .4

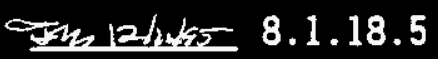

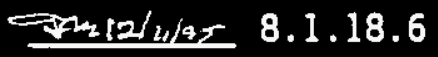

Press the SCROLL DOWN key to decrease the setpoint value ( 5 degrees with each press) that is flashing on the upper display until the setpoint value decreases past the present coolant temperature value that is showing on the lower display.

Verify the engine shuts down and that the shutdown indicator for high water temperature is flashing.

RETURN engine control switch to OFF position.

Turn engine control switch to MANUAL START position and run engine up to rated speed until coolant temperature exceeds $150^{\circ} \mathrm{F}$.

CLOSE generator mounted load bank circuit breaker.

Turn ON load bank power control switch and master control switch. ECN $w_{0} z_{0}-175$ Apply $50 \mathrm{KW}$ of load by turning load bank switch(es) ON. "Allow engine to
stabilize for a minimam of 15 minutas.

RECORD the following parameters:

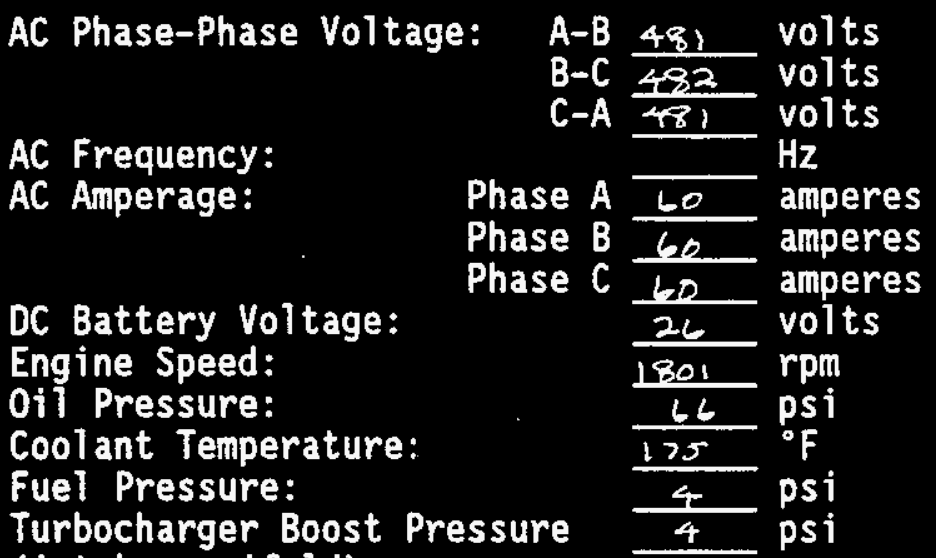

(intake manifold)

ECN wo30-175

Apply another $50 \mathrm{KW}$ of load turning load bank switch(es) ON." Allow engineRECORD the following parameters:

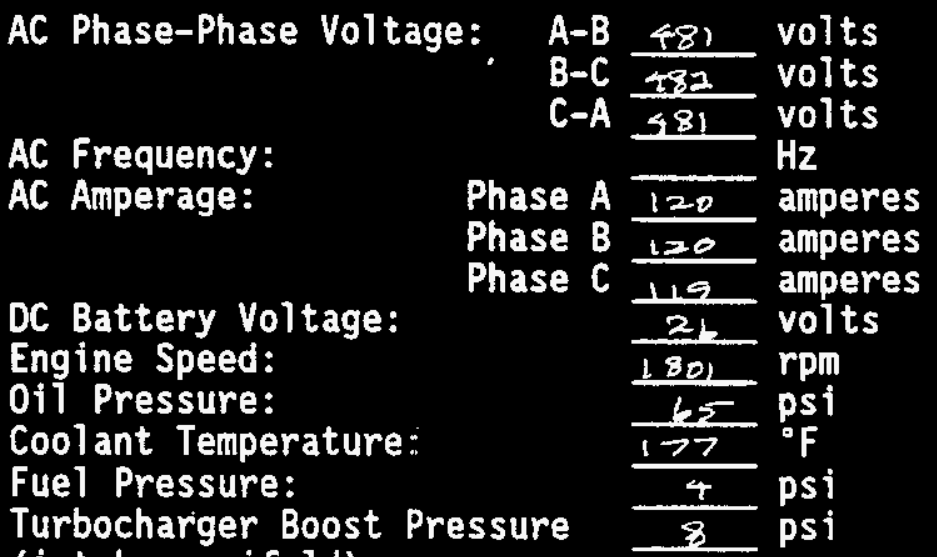
(intake manifold)

$$
E C N_{w 030-175}
$$

Apply the remaining $25 \mathrm{KW}$ of load by turning load bank switch ON. "Allow engine to stabilize for a minimum of 15 minutes"

W030007.ATP. 2456
WHC-SD-W030-ATR-007

Rev 0

$09 / 18 / 95$ 


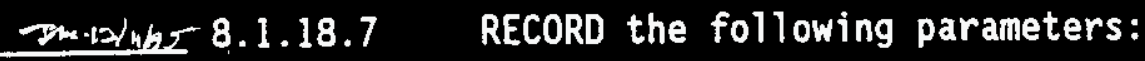

\begin{tabular}{|c|c|c|c|}
\hline AC Phase-Phase Voltage & $\begin{array}{l}A-B \\
B-C \\
C-A\end{array}$ & $\frac{481}{482}$ & $\begin{array}{l}\text { volts } \\
\text { volts } \\
\text { volts }\end{array}$ \\
\hline $\begin{array}{l}\text { C Frequen } \\
\text { C Amperag }\end{array}$ & $\begin{array}{l}\text { Phase A } \\
\text { Phase B } \\
\text { Phase C }\end{array}$ & $\frac{150}{\frac{150}{150}}$ & $\begin{array}{l}\mathrm{Hz} \\
\text { amperes } \\
\text { amperes } \\
\text { amperes }\end{array}$ \\
\hline $\begin{array}{l}\text { DC Battery Voltage: } \\
\text { Engine Speed: } \\
\text { oil Pressure: } \\
\text { Coolant Temperature: } \\
\text { Fuel Pressure: } \\
\text { Turbocharger Boost Pr } \\
\text { (intake manifold) }\end{array}$ & & $\frac{\frac{150}{26}}{\frac{1802}{179}} \frac{16}{\frac{4}{15}}$ & $\begin{array}{l}\text { aliper } \\
\text { volts } \\
\text { rpm } \\
\text { psi } \\
{ }^{\circ} \mathrm{F} \\
\mathrm{psi} \\
\mathrm{psi}\end{array}$ \\
\hline
\end{tabular}

Sm/2/12/s= 8.1.18.8

REMOVE load bank load by turning load switches to the OFF position. Turn OFF master control switch and power control switch.

$\cos 20 \sin 55$

8.1.18.9

OPEN generator mounted load bank circuit breaker.

8.1 .19

Allow diesel engine to run unloaded for approximately 15 minutes. PRESS emergency stop pushbutton. Verify engine STOPS.

somis/utat 8.1.20

$\operatorname{sen} 12 d v 100$ 8.1.21

Sonstulys 8.1.22

Thentulas 8.1.22.1

TURN emergency stop pushbutton clockwise until it releases. TURN engine control. switch to the OFF position.

INSTALL shorting jumper with ON-OFF switch between Terminals 33 and 34 on the generator control panel terminal strip. Ensure switch is in the OFF (normally open) position before connecting to terminals. The switch will be used to simulate the remote emergency stop signal.

TURN engine control switch to manual start and bring engine up to speed.

PLACE shorting jumper switch in the ON position. Verify engine STOPS.

In lafulas 8.1.22.2 TURN engine control switch to the OFF position. REMOVE shorting jumper.

END OF SECTION 8 
Simpluts 9.1 .1

$9 \min 2 / 25$

$=\min 1201059.1 .3$

sumelutss 9.1 .4

Simizlukr 9.1 .5

$\sin 12 \operatorname{uts} 59.1 .5 .1$

$=3.12 / 4659.1 .6$

$=\sin 12 / 4 / 259.1 .6 .1$

$\operatorname{sim} 12 / 4559.1 .7$

$\sin 12 / 4 / 559.1 .8$

Emplinte-9.1.9

Intzlupr 9.1.10
Verify normal power feeder circuit breaker to ATS 1 at Distribution Panelboard PP-1 is OPEN.

Verify engine control switch is in the OFF position. Verify generator circuit breakers (3) are OPEN.

Insert manual operator handle and operate the transfer switch between the NORMAL and EMERGENCY positions. Verify the transfer switch operates smoothly without binding. Return switch to the NORMAL position. Remove handle and place in holder provided.

RECORD the time delay settings of the following relays:

Pl (Time delay to engine start)

$T$ (Time delay on retransfer to normal)

$v$ (Engine over-run timer)

$W$ (Time delay on transfer to minutes

V (Time delay on transfer to emergency) $\frac{2}{2}$ seconds

CLOSE the normal power feeder circuit breaker to ATS i at Distribution Panelboard PP-1. Verify Normal Power Available Light (LNA) on bypass subpanel is ILLUMINATED.

RECORD phase-phase voltages at the Normal 1 ine input terminals:
$A-B 499$ volts
B-C 499 volts
C-A 493 volts

CLOSE the generator circuit breaker to ATS 1 . Turn engine control switch to Manual position to Start engine. Verify engine starts and Emergency Power Available Light (LEA) on bypass subpanel is ILLUMINATED.

RECORD phase-phase voltages at the Emergency line input terminals:

A-B 484 volts $B-C \underline{484}$ volts $\quad C-A 485$ volts

Verify the phase rotation of the Diesel Generator output conductors is the same as the phase rotation of the Normal power source.

Turn the engine control switch to the OFf position. Allow engine to come to a complete stop and verify Emergency Power Available Light (LEA) is OFF.

Turn the engine control switch to the AUTO position.

C1ose ATS 1 cabinet door. Verify Normal Power Light L2 is ILLUMINATED. Verify disconnect switch on ATS 1 is in the AUTO position. 


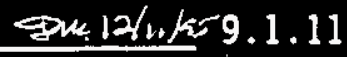

Fue 12/195 9.1.12

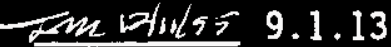

$\tan (2 / u / 959.1 .14$

Dine vinlss 9.1.15

Zumpolulas 9.1.16

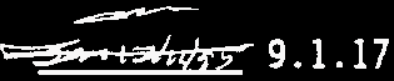

$=m_{12 / 1195}-1.18$

Exatulas 9.1 .19

andzulas 9.1.19.1

anniglas 9.1.19.2

temp/uter 9.1.19.3

Pmoduts 9.1.19.4

Duralutar 9.1.19.5

gmblester 9.1.19.6

ow relster 9.1.19.7

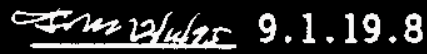

Imentos 9.1 .20

Tamp/nks 9.1 .21

Emadulez 9.1.21.1
PRESS the Test pushbutton (TS switch) and HOLD IN (do not release) to initiate and maintain a transfer from the Normal source to the Emergency source. Relay P1 will. time out and cause the diesel engine to START.

Verify engine STARTS.

Verify the ATS transfers to the Emergency source after the time delay of relay $W$. Verify Emergency Power Light $L l$ is ILLUMINATED and Normal Power Light L2 is OFF.

RELEASE test pushbutton (TS switch) to initiate the retransfer to the Norma1 source.

Verify the ATS retransfers to the Normal source after the time delay of relay $T$.

Verify the generator is still running and continues to run for the time delay of relay $U$. Verify engine has stopped. TURN the engine control switch to the OFf position.

OPEH the generator-circuit breaker-to-AFS-1. Step Deloted - ECN

TURN the engine control switch to manual start position and bring engine up to speed.

CLOSE generator load bank circuit breaker.

TURN ON load bank power control switch and master control switch.

Apply $50 \mathrm{KW}$ of load by turning load bank switch(es) $0 \mathrm{~N}$.

OPEN the normal power feeder circuit breaker to ATS TEECN woso-175

Verify load bank dumps (unloads) the $50 \mathrm{KW}$ load, "and that ATS 1 transfers to the emergency source." CLOSE the normal power feeder circuit breaker to ATS 1 at $P P_{-1}$ AT $P P_{-2}$

REMOVE $50 \mathrm{KW}$ of load by turning load bank switch(es) OFF.

TURN OFF load bank master control switch and power control switch.

OPEN generator load bank circuit breaker.

Delate fer ECN wo $3-75$

GLSt gehorator eiretitt-Greaker to AFS-1. TURN the engine control switch to the OFF position. Allow engine to come to a complete stop.

TURN the engine control switch to the AUTO position.

The next few steps will verify the diesel generator comes on and up to speed within 10 seconds of a loss of normal power:

OPEN the normal power feeder circuit breaker to ATS I at PP-1. Start timing from this point in time and Stop timing when ATS 1 transfers to the Emergency source. 
$=\min 12 / 11 / 259.1 .21 .2$

Fureluss 9.1.21.3

snzelutas 9.1 .21 .4

$=x^{2} p / 110-9.1 .21 .5$

$=21.21 .6$

Tumplat 9.1 .22

9.2 AUTOMATIC TRANSFER SWITCH NO. 2

To ensure ATS 2 will operate as intended.

amialuts5 9.2.1

smaptes 9.2.2

Injoluter 9.2 .3

Imladulas 9.2 .4

Taniz/us 9.2 .5

\#malubse 9.2 .5 .1
Verify engine starts and operates at rated speed.

RECORD time for transfer (should be 10 seconds or less):

Time for transfer 3.7 seconds.

CLOSE the normal power circuit breaker to ATS 1 at PP-1. Open generator circuit breaker to ATS 1. Verify ATS 1 switches to the Normal source without delay.

CLOSE the generator circuit breaker to ATS 1. OPEN the normal power circuit breaker to ATS 1 at PP-1. Verify ATS 1 switches to the Emergency source without delay.

CLOSE the normal power circuit breaker to ATS 1 at PP-1. Verify ATS 1 transfers to Normal source in $30 \pm 5$ minutes. Verify engine runs for approximately 4-7 minutes and Stops.

OPEN the generator circuit breaker to ATS 1. RETURN engine control switch to the OFF position. OPEN the normal power circuit breaker to ATS 1 at PP-1.

Verify normal power feeder circuit breaker to ATS 2 at Distribution Panelboard PP-2 is OPEN.

Verify engine control switch is in the OFF position. Verify generator circuit breakers (3) are OPEN.

Insert manual operator handle and operate the transfer switch between the NORMAL and EMERGENCY positions. Verify the transfer switch operates smoothly without binding. Return switch to the NORMAL position. Remove handle and place in holder provided.

RECORD the time delay settings of the following relays:

P1 (Time delay to engine start)

$T$ (Time delay on retransfer to normal)

$U$ (Engine over-run timer)

$W$ (Time delay on transfer to emergency)

$\frac{1.5}{30}$ seconds
$\frac{103 \text { minutes }}{2}$
minutes

CLOSE the normal power feeder circuit breaker to ATS 2 at Distribution Panelboard PP-2. Verify Normal Power Available Light (LNA) on bypass subpanel is ILLUMINATED.

RECORD phase-phase voltages at the Nomal line input terminals:
$A-B 500$ volts
B-C 300 volts
C-A 493 volts 
senizluls 9.2 .6

tmizlngr 9.2.6.1

$\sin 12 / 4 / 2=9.2 .7$

In $12 / 4 / 959.2 .8$

\#w12/uss 9.2 .9

Damplutar 9.2 .10

matulas 9.2.11

PmadutsT 9.2.12

mizluks 9.2.13

$\sin 12 / 11 / 959.2 .14$

Pma/1/55 9.2 .15

tmandulss 9.2 .16

$M / A B_{1.19 .96} 9.2 .17$

9.2.18

9.2.19

thn 12 delso-9.2.19.1

Therater 9.2.19.2

Imwlat 9.2.19.3
CLOSE the generator circuit breaker to ATS 2. Turn engine control switch to Manual position to Start engine. Verify engine starts and Emergency Power Available Light (LEA) on bypass subpanel is ILLUMINATED.

RECORD phase-phase voltages at the Emergency line input terminals:

A-B 484 volts $B-C 485$ volts $\quad C-A 485$ volts

Verify the phase rotation of the Diesel Generator output conductors is the same as the phase rotation of the Normal power source.

Turn the engine control switch to the OFF position. Allow engine to come to a complete stop and verify Emergency Power Available Light (LEA) is OFF.

Turn the diesel engine control switch to the AUTO position.

Close ATS 2 cabinet door. Verify Normal Power Light L2 is ILLUMINATED. Verify disconnect switch on ATS 2 is in the AUTO position.

PRESS the Test pushbutton (TS switch) and HOLD IN (do not release) to initiate and maintain a transfer from the Normal source to the Emergency source. Relay P1 will time out and cause the diesel engine to START.

Verify engine STARTS.

Verify the ATS transfers to the Emergency source after the time delay of Relay $W$. Verify Emergency Power Light L1 is ILLUMINATED and Normal Power Light L2 is OFF.

RELEASE test pushbutton (TS switch) to initiate the retransfer to the Normal source.

Verify the ATS retransfers to the Normal source after the time delay of Relay $T$.

Verify the generator is still running and continues to run for the time delay of Relay $U$. Verify engine has stopped. TURN the engine control switch to the OFF position.

OpEN the-generator circuit breaker-to-AFS-2. step Deleted - ECN W030-175

FUAI the engine controf switch- to manual start position-and-bring engine up to speeds STep deleted TE-00J

-EtOSE generatop- foad bank-eiretit-breaker, sTeps Deleted TE- 002

FUnif of Totd bank-power-control switeh and master control switeh.

Apply $50 \mathrm{KW}$ of Toad by turning load bank switch fest ON.

OPEN the norinat power fecter cireuit breaker to ATS-2 at PP=2: 


\section{$\operatorname{ECN} \omega_{030}-175$}

Entaluts 9.2.19.4

genblutar 9.2 .19 .5

Tanulates 9.2.19.6

$\sin 12 \sin 1259.2 .19 .7$

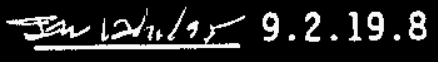

Imulatar 9.2 .20

$\tan (2 / x)=2.21$

andulas 9.2.21.1

9.2.21.2

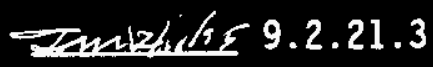

Imaluter 9.2.21.4

9.2 .21 .5

Exazhes, 9.2.21.6

$\min 121420.2 .22$

\subsection{AUTOMATIC TRANSFER SWITCH NO. 3}

To ensure ATS 3 will operate as intended.

$B B \cdot 12 \cdot 12.95-9.3 .1$

$3 B \cdot 12 \cdot 12.95=9.3 .2$
Vepify-load bank dumps funtoads the 50 KH Toad and that AfS 2 CLOSE the-normat power feeder otrcuit breaker to-ATS 2-at PR-2

REMOVE $50 \mathrm{KN}$ of Toad by turning load bank switeh(es)-OFF. STePs Deleted FURN OFF toad bank master cont pol-switeh and power control switch. $T_{E-002}$ OPEN-gemerator Toad bank circuit breaker.

Pefte per ECN w030-175 switch to the OFF position. Allow engine to come to a complete stop.

TURN the engine control switch to the AUTO position.

The next few steps will verify the diesel generator comes on and up to speed within 10 seconds of a loss of normal power:

OPEN the normal power feeder circuit breaker to ATS 2 at PP-2. Start timing from this point in time and Stop timing when ATS 2 transfers to the Emergency source.

Verify engine starts and operates at rated speed.

RECORD time for transfer (should be 10 seconds or less):

Time for transfer 4 seconds.

CLOSE the norma1 power circuit breaker to ATS 2 at PP-2. Open generator circuit breaker to ATS 1. Verify ATS 2 switches to the Normal source without delay.

CLOSE the generator circuit breaker to ATS 2. OPEN the normal power circuit breaker to ATS 2 at PP-2. Verify ATS 2 switches to the Emergency source without delay.

CLOSE the normal power circuit breaker to ATS 2 at PP-2. Verify ATS 2 transfers to Normal source in $30 \pm 5$ minutes. Verify engine runs for approximately 4-7 minutes and Stops.

OPEN the generator circuit breaker to ATS 2. RETURN engine control switch to the OFF position. OPEN the normal power circuit breaker to ATS 2 at PP-2.
Verify circuit breakers feeding ATS 3 at Standby Panelboard No. 1 and Standby Panelboard No. 2 are OPEN.

Verify input circuit breaker (CB1) in UPS No. 3 is OPEN. 
38.12 .12959 .3 .3

$B B_{12.1295} 9.3 .3 .1$

$B B \cdot 12 \cdot 12.959 .3 .4$

$33-12 \cdot 12-95 \quad 9.3 .4 .1$

$38.12 \cdot 12.959 .3 .5$

BB.12.12.95 9.3.6

$3 B 12 \cdot 12.959 .3 .7$

$B B 12.12 .959 .3 .8$

3812.12 .959 .3 .9

B.3 12.12 .959 .3 .10
CLOSE the normal power circuit breaker to ATS 1 at PP-1. CLOSE circuit breaker at Standby Panelboard No. 1 that feeds ATS 3.

RECORD phase-phase input voltages from Standby Panelboard No. 1 at ATS 3:

A-B 503 volts B-C 502 volts $\quad$ C-A 497 volts

CLOSE the normal power circuit breaker to ATS 2 at PP-2. CLOSE circuit breaker at Standby Panelboard No. 2 that feeds ATS 3.

RECORD phase-phase input voltages from Standby Panelboard No. 2 at ATS 3:
A-B 503 volts
B-C 502 volts
C-A 497 volts

Verify ATS 3 is in the Normal power operating position.

RECORD the Standby Panelboard number that feeds the Normal power terminals in ATS 3 and the Standby Panelboard number that feeds the Emergency power terminals in ATS 3:

Power to normal power terminals in ATS 3 is supplied from Standby Panelboard No.

Power to energency power terminals in ATS 3 is supplied from Standby Panelboard No.

OPEN Normal power circuit breaker at corresponding standby panelboard and verify ATS 3 transfers to the terminals marked Emergency power source.

CLOSE Normal power circuit breaker at corresponding standby panelboard and verify ATS 3 retransfer to the terminals marked Normal power source.

OPEN circuit breaker at Standby Panelboard No. 2 that feeds ATS 3. OPEN circuit breaker at Standby Panelboard No. 1 that feeds ATS 3. 
NOTE: $\quad$ The digital monitoring panel may have arrow markings instead of words below the pushbuttons. References to the pushbuttons for this test and on the screen use words. The arrows and the words correlate as follows:

$\rightarrow=$ NEXT; $\quad+=$ PREVIOUS; $\uparrow=$ UP; $\quad \downarrow=$ DOWN; $\quad\rfloor=$ ENTER

CAUTION: Always be aware that hazardous voltages may be present within the UPS even when the system is not operating.

10.1 UPS NO. 1 WITH PANELBOARD UPS-PP-13

To ensure UPS No. 1 can be energized and is ready for normal operation.

$B B+12 \cdot 12.9510 .1 .1$

$B B+2 \cdot 12.9510 .1 .2$

$B B+12 \cdot 12-9510.1 .3$

$B B+2-12.9510 .1 .3 .1$

$P B$ 12.12.95 10.1 .4

PB $12.12 .95 \quad 10.1 .4 .1$

10.1 .4 .2

$B B+2-12.9510 .1 .5$

$3 B+2.12 .9510 .1 .6$

$281-19.96 \quad 10.1 .7$

$B B 12 \cdot 12.9510 .1 .7 .1$
Verify feeder circuit breaker to UPS No. 1 at Standby Panelboard No. 1 is OPEN.

Verify all UPS No. 1 circuit breakers/switches including battery circuit breaker (CB3) and UPS-PP-13 main circuit breaker (CB4) are OPEN.

CLOSE feeder circuit breaker to UPS No. 1 at Standby Panelboard No. 1 .

RECORD input phase-phase voltage at line terminals of UPS input power terminal block:
$A-B$ SO3volts
B-C 503 volts
C-A 498_volts

Rotate UPS Control Switch knob clockwise to ON position.

Verify message screen reads "CHECKSUM GOOD".

Verify the following LEDs are ILLUMINATED:

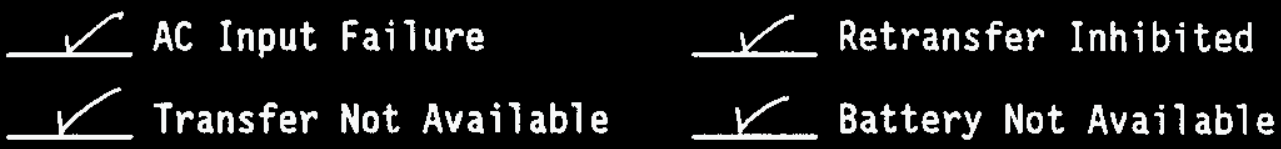

Verify message screen reads "CLOSE BYPASS CKT.BREAKER". CLOSE the bypass circuit breaker (CB2). The same LEDs in Step 10.1.4.2 should be ILLUMINATED.

Verify message screen reads "CLOSE INPUT CKT.BREAKER". CLOSE the input circuit breaker (CB1). Message screen will read "WAITING DC LINK $=X X X . X$ VDC" for a short time. $X X X . X$ represents the actual voltage as displayed.

Verify message screen reads "CLOSE BATTERY CKT.BREAKER". CLOSE

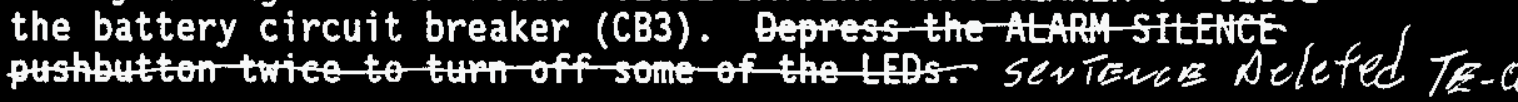

Verify the "Transfer Not Available" LED is the only LED ILLUMINATED. 
$3 B .22 .129510 .1 .8$

$B B_{12.12 .95} 10.1 .8 .1$

$38+2.12 .95 \quad 10.1 .9$

3812.12 .95 10.1.9.1

$38.12 \cdot 12.9510 .1 .10$

38.12 .12 .95 10.1.10.1

$B B 12-12.95$ 10.1.10.2

BB.12.12.95 10.1.11

$3 B 12.12 .9510 .1 .12$

3812.12 .9510 .1 .13

BB.12-12.95 10.1.13.1

$B B 12.12 .95$ 10.1.13.2

10.1 .14

$B 3 / 2.12 .95-10.1 .14 .1$
Verify message screen reads "CLOSE OUTPUT SWTCH OR BKR". CLOSE the inverter output switch (S1).

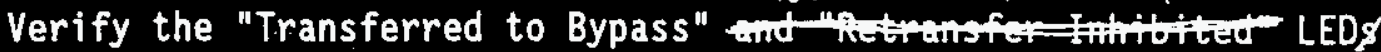
are ILLUMINATED.

Verify message screen reads "CLOSE SBS OUTPUT CKT.BREAKER". CLOSE static bypass output switch (S2).

Verify the same LEDs in Step 10.1.8.1 are ILLUMINATED.

Verify message screen reads "OPEN BYPASS CKT.BREAKER". OPEN the bypass circuit breaker (CB2).

Verify the audible alarm sounds within approximately 2 minutes. Depress the "ALARM SILENCE" pushbutton which will silence the alarm and turn the 2 LEDs off.

Verify the "UPS Normal" LED is ILLUMINATED.

Verify message screen reads "WAIT RETRANSFER PENDING" for a short period of time. Verify message screen then reads "UPS OPERATING NORMALLY".

RECORD UPS output phase-phase and phase-neutral voltages preferably at Panelboard UPS-PP-13 main circuit breaker line side. Phase-phase voltage readings should be nominal 208 volts. Phaseneutral voltage readings should be nominal 120 volts.

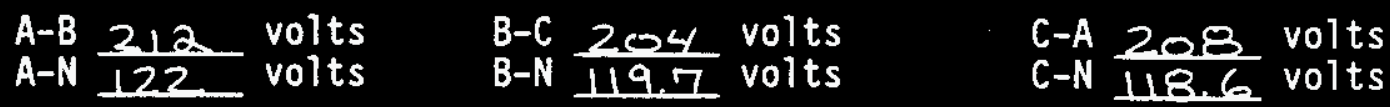

CLOSE Panelboard UPS-PP-13 main circuit breaker (CB4).

RECORD Panelboard UPS-PP-13 phase-phase and phase-neutral

voltages. Nominal voltage readings should be the same as shown in Step 10.1.12.

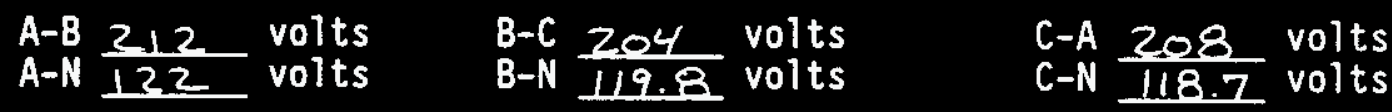

OPEN Panelboard UPS-PP-13 main circuit breaker (CB4).

The following steps will be used to record input/output voltages and amperes and other parameters by viewing the message screens on the digital monitoring panel. To scroll through the different screens, depress "Next" or "Previous" pushbuttons beneath Display Select:

SCROLL screens to "INPUT VOLTAGE" and RECORD input voltage between phases:
A-B 495 volts
B-C 500 volts
C-A 503 volts 
$B B 12.12 .9510 .1 .14 .2$

$B B \cdot 2 \cdot 12.95,10 \cdot 1 \cdot 14.3$

$B 8 \cdot 2-12.95 \quad 10.1 \cdot 14.4$

$8812 \cdot 12.95,10.1 \cdot 14.5$

$B B 12 \cdot 12.9510 .1 \cdot 14.6$

$B B 12.12 .9510 .1 .15$

$B B 12.12 .95-10.1 .15 .1$

$B B 12-12.9510 .1 \cdot 15.2$

$B B \cdot 12 \cdot 12.9510 .1 .15 .3$

10.1 .16

$38.12 \cdot 12.95-10.1 .16 .1$
SCROLL screens to "INPUT CURRENT" and RECORD input current per phase:

Ia 2.7 amperes Ib 2.9 amperes Ic 2.8 amperes

SCROLL screens to "FREQUENCIES/TEMPERATURE" and RECORD frequencies and temperature:

Input Frequency $60 \mathrm{~Hz} \quad$ Output Frequency $59.9 \mathrm{HZ}$

Inlet Temperature $10.6^{\circ} \mathrm{C}$

SCROLL screens to "LINK VOLTAGE" and RECORD DC link voltage, battery amperage and maximum output crest factor:

Link Voltage 245.1 volts DC Battery Current .7 amperes

Max Out CF $€$

SCROLL screens to "OUTPUT POWER" and RECORD output power parameters:

Output KVA $\odot$ Output KW $\odot$ Power Factor $\odot$

SCROLL screens to "OUTPUT VOLTAGE" and RECORD output phase neutral voltage:

A-N 121 volts $B-N 120$ volts $\quad \mathrm{C}-\mathrm{N} \perp 18$ volts

SCROLL screens to "OUTPUT CURRENT" and RECORD output phase current:

Ia $\theta$ amperes Ib $\theta$ amperes Ic $\theta$ amperes

SCROLL screens until message screen reads "UPS OPERATING NORMALLY".

OPEN feeder circuit breaker at Standby Panelboard No. 1. Verify "AC Input Failure" LED is ILLUMINATED.

RECORD run time left on battery and link voltage:

Run Time Remaining 9 H $6{ }^{M} 7 \mathrm{~s}$

Link Voltage 224 volts $D C$

CLOSE feeder circuit breaker at Standby Panelboard No. 1. Verify "AC Input Failure" LED is NOT ILLUMINATED. Verify screen reads "UPS OPERATING NORMALLY" and the "UPS Normal" LED is ILLUMINATED.

The following steps will shut down the UPS system:

SCROLL screens by using the "Next" pushbutton until the screen reads "UPS MAINTENANCE MENU". Press the "Enter" pushbutton. Screen will read "ENTER PASSWORD". 
Depress the "Up" pushbutton until the digit "4" appears on the screen. Depress the "Next" pushbutton to activate the second digit and depress the "Up" or "Down" pushbuttons until the digit "F". appears on the screen. Depress the "Next" pushbutton to activate the third digit and depress the "Up" or "Down" pushbuttons until the digit " 0 " appears on the screen. Depress the "Next" pushbutton to activate the fourth digit and depress the "Up" or "Down" pushbuttons until the digit " 0 " appears on the screen.

$3 B 12 \cdot 12.9510 .1 \cdot 16.3$

$3 B_{12}-12.9510 .1 \cdot 16.4$

$B B_{12} \cdot 12.9510 .1 \cdot 16.5$

7812.12 .9510 .1 .16 .6

$B B 12 \cdot 12.9510 .1 \cdot 16.7$

$B B / 2.129510 .1 \cdot 16.8$

$B B .12 \cdot 12.9510 .1 \cdot 16.9$

$B B+2.12 .95=10.1 \cdot 16.10$

10.2 UPS NO. 2 WITH PANELBOARD UPS-PP-14 No. 1 .
$B B \cdot 12.12 .9510 .2 .1$

$B 312-1229510.2 .2$
Depress the "Enter" pushbutton to bring up the first of the secondary menus. Depress the "Next" or "Previous" pushbuttons to advance to the SBS Maintenance Menu and depress the "Enter" pushbutton. Depress the "Up" pushbutton to begin the Bypass/ Shutdown Procedure. The message screen will show "CONFIRM", depress the "Up" pushbutton for Yes.

Verify the message screen reads "CLOSE BYPASS BREAKER". CLOSE the bypass circuit breaker (CB2).

Verify the message screen reads "OPEN OUTPUT BREAKER". OPEN UPS inverter output switch (S1).

$$
\text { OUTAUT TE-0O5 }
$$

Verify the message screen reads "OPEN SBS PIPUT BREAKER". OPEN the static bypass output switch (S2).

Verify the message screen reads "OPEN BATTERY BREAKER". OPEN the battery circuit breaker (CB3).

Verify the message screen reads "OPEN INPUT BREAKER". OPEN input circuit breaker (CB1). When the link voltage has decreased to the proper value verify the message screen reads "WAITING DC LINK = $X X X . X$ VDC". XXX.X represents the actual voltage as displayed.

Verify the message screen reads "BYPASS/SHUTDOWN COMPLETE". Rotate UPS control switch counterclockwise to the OFF position. OPEN the bypass circuit breaker (CB2).

OPEN feeder circuit breaker to UPS No. 1 at Standby Panelboard

To ensure UPS No. 2 can be energized and is ready for normal operation.

Verify feeder circuit breaker to UPS No. 2 at Standby Panelboard No. 2 is OPEN.

Verify all UPS No. 2 circuit breakers/switches including battery circuit breaker (CB3) and UPS-PP-14 main circuit breaker (CB4) are OPEN. 
$B B .12 .12 .9510 .2 .3$

$38.12 .12 .95 \quad 10.2 .3 .1$

$B B 12.12 .9510 .2 .4$

$3312.12 .95,10.2 .4 .1$

3812.12 .9510 .2 .4 .2

$\beta 312.12 .9510 .2 .5$

3812.12 .9510 .2 .6

$28+12-19.9510 .2 .7$

$3312.12 .95 \quad 10.2 .7 .1$

3.12 .12 .9510 .2 .8

$321-19.96210 .2 .8 .1$

3312.12 .9510 .2 .9

$B B 12.12 .95 \quad 10.2 .9 .1$

BB.12.12.95 10.2.10

$33.12 .19 .95-10.2 .10 .1$

$3712.12 .95-10.2 .10 .2$

CLOSE feeder circuit breaker to UPS No. 2 at Standby Panelboard No. 2.

RECORD input phase-phase voltage at line terminals of UPS input power terminal block:
A-B 502 volts
B-C 502 volts
C-A 498 volts

Rotate UPS Control Switch knob clockwise to ON position.

Verify message screen reads "CHECKSUM GOOD".

Verify the following LEDs are ILLUMINATED:

$\measuredangle$ AC Input Failure

$\mathcal{L}$ Transfer Not Available

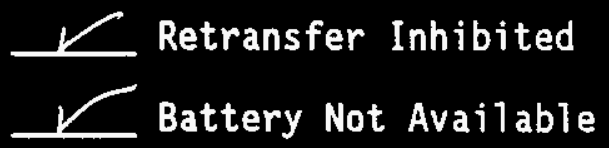

Verify message screen reads "CLOSE BYPASS CKT.BREAKER". CLOSE the bypass circuit breaker (CB2). The same LEDs in Step 10.2.4.2 should be ILLUMINATED.

Verify message screen reads "CLOSE INPUT CKT.BREAKER". CLOSE the input circuit breaker (CB1). Message screen will read "WAITING DC, LINK $=X X X . X V V^{\prime \prime}$ for a short time. $X X X . X$ represents the actual voltage as displayed.

Verify message screen reads "CLOSE BATTERY CKT.BREAKER". CLOSE the battery circuit breaker (CB3). Bepress the-ALAAM-SItEALE pushbutten twite- to turn off some- of the-LESs seviEva DELETED TE-D.

Verify the "Transfer Not Available" LED is the only LED ILLUMINATED.

Verify message screen reads "CLOSE OUTPUT SWTCH OR BKR". CLOSE the inverter output switch (S1).

Verify the "Transferred to Bypass" DELETED TE-004 are ILLUMINATED.

Verify message screen reads "CLOSE SBS OUTPUT CKT.BREAKER". CLOSE static bypass output switch (\$2).

Verify the same LEDs of Step 10.2.8.1 are ILLUMINATED.

Verify message screen reads "OPEN BYPASS CKT.BREAKER". OPEN the bypass circuit breaker (CB2).

Verify the audible alam sounds within approximately 2 minutes. Depress-the-AtARM-SILENCE pustbutten which-witl stlence the ataril and-turn the 2 tEPs off Sev TewCe DeleYed TE-003.

Verify the "UPS Normal" LED is ILLUMINATED. 
$283 \cdot 2 \cdot 12.9510 .2 .11$

P $12 \cdot 12.9510 .2 .12$

$3 B 12 \cdot 12.9510 .2 .13$

$B B .12 .12 .9510 .2 .13 .1$

$B B 12.12-9570.2 .13 .2$

10.2 .14

$B B \cdot 12 \cdot 12.9510 .2 \cdot 14.1$

$3 B .2 .12 .95,10.2 .14 .2$

$B R \cdot 2 \cdot 12.9510 \cdot 2 \cdot 14.3$

$B B 12.129510 .2 .14 .4$
Verify message screen reads "WAIT RETRANSFER PENDING" for a short period of time. Verify message screen then reads "UPS OPERATING NORMALLY".

RECORD UPS output phase-phase and phase-neutral voltages preferably at Pane1board UPS-PP-14 main circuit breaker line side. Phase-phase voltage readings should be nominal 208 volts. Phaseneutral voltage readings should be nominal 120 volts.
A-B $\frac{211.6 \text { volts }}{120.1}$ volts
B-N $\frac{209.1 \text { volts }}{121.5}$ volts
C-A 203.9 volts
C-N $\frac{203.9}{119.0}$ volts

CLOSE Panelboard UPS-PP-14 main circuit breaker (CB4).

RECORD Panelboard UPS-PP-14 phase-phase and phase-neutral

voltages. Nominal voltage readings should be the same as shown in Step 10.2.12.
$A-B \frac{211.6}{120.1}$ volts
B-C 209.1 volts
$B-N \frac{2.2 .5}{12.5}$ volts
C-A 203.9 volts
C-N 119.0 volts

OPEN Panelboard UPS-PP-14 main circuit breaker (CB4).

The following Steps will be used to record input/output voltages and amperes and other parameters by viewing the message screens on the digital monitoring panel. To scroll through the different screens, depress "Next" or "Previous" pushbuttons beneath Display Select:

SCROLL screens to "INPUT VOLTAGE" and RECORD input voltage between phases:

A-B.494.2 volts $\quad B-C 499.3$ volts $\quad C-A$ S02.7 volts

SCROLL screens to "INPUT CURRENT" and RECORD input current per phase:

Ia 2.7 amperes Ib 2.6 amperes Ic 2.5 amperes

SCROLL screens to "FREQUENCIES/TEMPERATURE" and RECORD frequencies and temperature:

Input Frequency 60.0 HZ Output Frequency $60.0 \mathrm{HZ}$

Inlet Temperature $11.9{ }^{\circ} \mathrm{C}$

SCROLL screens to "LINK VOLTAGE" and RECORD DC 1 ink voltage, battery amperage and maximum output crest factor:

Link Voltage 245.2 volts DC Battery Current 1.0 amperes

Max Out CF $=$ 
$B B_{12.12 .95} 10.2 .14 .5$

$B B 12.12 .95 \quad 10.2 .14 .6$

BB 12.12-95 10.2.14.7

3812.12 .9510 .2 .15

312.12 .9510 .2 .15 .1

$B 312.12 .95 \quad 10.2 .15 .2$

$B B+2.12 .9510 .2 .15 .3$

10.2 .16

$B B / 2.12 .9510 .2 .16 .1$

$B B_{12.12 .95} 10.2 .16 .2$

$B B-12.12 .95-10.2 \cdot 16.3$

$B B 12 \cdot 12.9510 .2 \cdot 16.4$
SCROLL screens to "OUTPUT POWER" and RECORD output power parameters:

Output KVA Output KW Power Factor SCROLL screens to "OUTPUT VOLTAGE" and RECORD output phase neutral voltage:

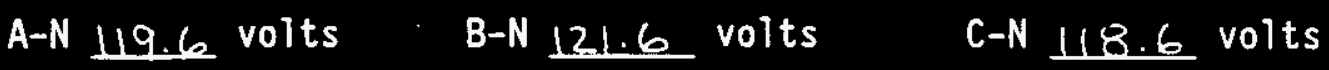
SCROLL screens to "OUTPUT CURRENT" and RECORD output phase current:

Ia $\odot$ amperes Ib $\Theta$ amperes Ic $\rightleftharpoons$ amperes

SCROLL screens until message screen reads "UPS OPERATING NORMALLY".

OPEN feeder circuit breaker at Standby Panelboard No. 2. Verify "AC Input Failure" LED is ILLUMINATED.

RECORO run time left on battery and link voltage:

Run Time Remaining $9 \mathrm{H}_{6}^{\mathrm{M}} \mathrm{7}$ s

Link Voltage 236.0 volts DC

CLOSE feeder circuit breaker at Standby Panelboard No. 2. Verify "AC Input Failure" LED is NOT ILLUMINATED. Verify screen reads "UPS OPERATING NORMALLY" and the "UPS Normal" LED is ILLUMINATED.

The following steps will shut down the UPS system:

SCROLL screens by using the "Next" pushbutton until the screen reads "UPS MAINTENANCE MENU". Press the "Enter" pushbutton. Screen will read "ENTER PASSWORD".

Depress the "Up" pushbutton until the digit "4" appears on the screen. Depress the "Next" pushbutton to activate the second digit and depress the "Up" or "Down" pushbuttons until the digit "F" appears on the screen. Depress the "Next" pushbutton to activate the third digit and depress the "Up" or "Down" pushbuttons until the digit " 0 " appears on the screen. Depress the "Next" pushbutton to activate the fourth digit and depress the "Up" or "Down" pushbuttons until the digit " 0 " appears on the screen.

Depress the "Enter" pushbutton to bring up the first of the secondary menus. Depress the "Next" or "Previous" pushbuttons to advance to the SBS Maintenance Menu and depress the "Enter" pushbutton. Depress the "Up" pushbutton to begin the Bypass/ Shutdown Procedure. The message screen will show "CONFIRM", depress the "Up" pushbutton for Yes.

Verify the message screen reads "CLOSE BYPASS BREAKER". CLOSE the bypass circuit breaker (CB2). 
$3 B .12 \cdot 12.9610 \cdot 2 \cdot 16.5$

B 10.996 .16 .6

$3812 \cdot 12.9510 .2 .16 .7$

B8.12.12.95 10.2 .16 .8

38.12 .12 .9510 .2 .16 .9

88.12 .12 .9510 .2 .16 .10

10.3 UPS NO. 3 WITH PANELBOARD UPS-PP-15

To ensure UPS No. 3 can be energized and is ready for normal operation.

$B B 12.12 .9510 .3 .1$

$3812.12 .95 \quad 10.3 .2$

$8 B 12 \cdot 12.95 \quad 10.3 .3$

$B B 12.12 .95-10.3 \cdot 3.1$

$38.12-12.9510 .3 .4$

B8.12-12.95 10.3.4.1

$8 B-12.12 .9510 .3 .4 .2$

$B B \cdot 12 \cdot 12.9510 .3 .5$
Verify the message screen reads "OPEN OUTPUT BREAKER". OPEN UPS inverter output switch (SI).

ourpat TE-005

Verify the message screen reads "OPEN SBS HPHF BREAKER". OPEN the static bypass output switch (S2).

Verify the message screen reads "OPEN BATTERY BREAKER". OPEN the battery circuit breaker (CB3).

Verify the message screen reads "OPEN INPUT BREAKER". OPEN input circuit breaker (CB1). When the link voltage has decreased to the proper value verify the message screen reads "WAITING DC LINK = $X X X . X$ Vdc. $X X X . X$ represents the actual voltage as displayed.

Verify the message screen reads "BYPASS/SHUTDOWN COMPLETE". Rotate UPS control switch counterclockwise to the "OFF" position. OPEN the bypass circuit breaker (CB2).

OPEN feeder circuit breaker to UPS No. 2 at Standby Panelboard No. 2.
Verify feeder circuit breakers to Transfer Switch No. 3 at Standby Panelboard No. 1 and Standby Panelboard No. 2 are OPEN.

Verify all UPS No. 3 circuit breakers/switches including the battery circuit breaker (CB3) and UPS-PP-15 main circuit breaker (CB4) are OPEN.

CLOSE feeder circuit breaker to Automatic Transfer Switch No. 3 at Standby Panelboard No. 1 .

RECORD input phase-phase voltage at line terminals of UPS input power terminal block:
A-B 503 volts
B-C 503 volts
C-A 497 volts

Rotate UPS control switch knob clockwise to ON position.

Verify message screen reads "CHECKSUM COOD".

Verify the following LEDs are ILLUMINATED:

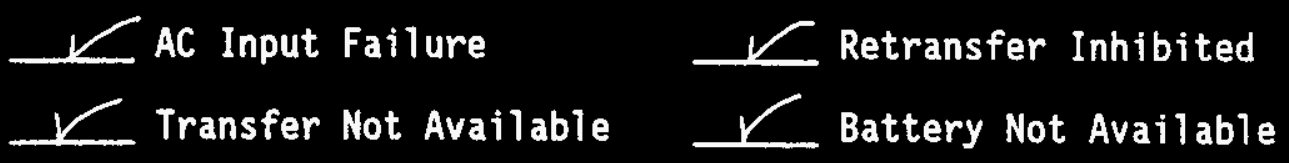

Verify message screen reads "CLOSE BYPASS CKT.BREAKER". CLOSE the bypass circuit breaker (CB2). The same LEDs in Step 10.3.4.2 should be ILLUMINATED. 
¿.6 Verify message screen reads "CLOSE INPUT CKT.BREAKER". CLOSE the input circuit breaker (CB1). Message screen will read "WAITING DC LINK $=X X X . X$ VDC" for a short time. XXX.X represents the actual voltage as displayed.

$\therefore 10.3 .7$

12.12 .9510 .3 .7 .1

$B .12 .12 .95$ C 10.3 .8

$38.12 .95 \quad 10.3 .8 .1$

38.12 .12 .9510 .3 .9

$88.12 .12 .95 \quad 10.3 .9 .1$

38.12 .9510 .3 .10

$B B \cdot 12.12 .95$ 10.3.10.1

$B B 12-12.95$ 10.3.10.2

83.12 .12 .9510 .3 .11

$38.12 .12-95-10.3 .12$

38.12 .12 .9510 .3 .13

$B 8-12.12 .9510 .3 .13 .1$

812.12 .9510 .3 .13 .2
Verify message screen reads "CLOSE BATTERY CKT.BREAKER". CLOSE the battery circuit breaker (CB3). Bepress the-ALARM-SHLENGE pushbutton twice to turn off some of the LEDS. SEUTEWCE DELETEO $T E-003$

Verify the "Transfer Not Available" LED is the only LED ILLUMINATED.

Verify message screen reads "CLOSE OUTPUT SWTCH OR BKR". CLOSE the inverter output switch (S1).

$$
\text { Deleted TE- Dou }
$$

Verify the "Transferred to Bypass" and-Retrasfer Inhibited" LEDg are ILLUMINATED.

Verify message screen reads "CLOSE SBS OUTPUT CKT.BREAKER". CLOSE static bypass output switch (S2).

Verify the same LEDs in Step 10.3.8.1 are ILLUMINATED.

Verify message screen reads "OPEN BYPASS CKT.BREAKER". OPEN the bypass circuit breaker (CB2).

Verify the audible alarm sounds within approximately 2 minutes. Depress the ALARM SILENCE pushbutton which will silence the alarm and turn the 2 LEDs off.

Verify the "UPS Normal" LED is ILLUMINATED.

Verify message screen reads "WAIT RETRANSFER PENDING" for a short period of time. Verify message screen then reads "UPS OPERATING NORMALLY".

RECORD UPS output phase-phase and phase-neutral voltages preferably at Panelboard UPS-PP-15 main circuit breaker 1 ine side. Phase-phase voltage readings should be nominal 208 volts. Phaseneutral voltage readings should be nominal 120 volts.
A-N $\frac{210}{120.3}$ volts
B-C 207.8 volts
C-A $\frac{207.6 \text { volts }}{119.9 \text { volts }}$

CLOSE Panelboard UPS-PP-15 main circuit breaker (CB4).

RECORD Panelboard UPS-PP-15 phase-phase and phase-neutral voltages. Nominal voltage readings should be the same as shown in Step 10.3.12.

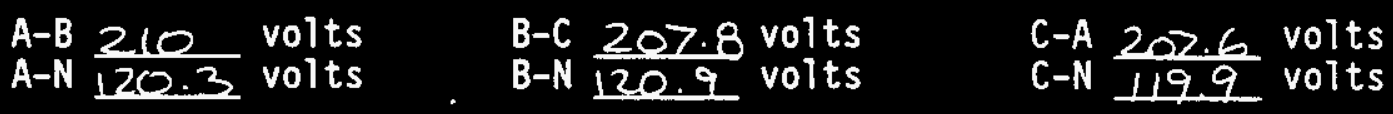
OPEN Panelboard UPS-PP-15 main circuit breaker (CB4). 
10.3.14 The following Steps will be used to record input/output voltages and amperes and other parameters by viewing the message screens on the digital monitoring panel. To scroll through the different screens, depress "Next" or "Previous" pushbuttons beneath Display Select:

PB. $12.12 .95=10.3 \cdot 14.1$ SCROLL screens to "INPUT VOLTAGE" and RECORD input voltage between phases:
A-B 494.5 volts
B-C 501.9 volts
C-A So2.1 volts

$8 B 12 \cdot 12.9510 .3 \cdot 14.2$

SCROLL screens to "INPUT CURRENT" and RECORD input current per phase:

Ia 2.5 amperes Ib 2.6 amperes Ic 2.5 amperes

$B B 12.12-95$ 10.3.14.3 SCROLL screens to "FREQUENCIES/TEMPERATURE" and RECORD frequencies and temperature:

Input Frequency $59.99 \mathrm{HZ}$

Output Frequency $59.99 \mathrm{HZ}$

Inlet Temperature $16.4^{\circ} \mathrm{C}$

$B B .12 \cdot 12.9510 .3 .14 .4$

SCROLL screens to "LINK VOLTAGE" and RECORD DC link voltage, battery amperage and maximum output crest factor:

Link. Voltage 245.6 volts DC Battery Current 2.1 amperes

Max Out CF

BB 12.1295 10.3.14.5 SCROLL screens to "OUTPUT POWER" and RECORD output power parameters:

Output KVA $\Theta$ Output KW Power Factor

RB.12.12.95 10.3.14.6 SCROLL screens to "OUTPUT VOLTAGE" and RECORD output phase neutral voltage:

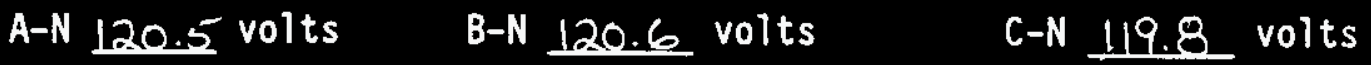

BB 12.12.95 10.3.14.7 SCROLL screens to "OUTPUT CURRENT" and RECORD output phase current:

Ia $\rightleftharpoons$ amperes Ib $\rightleftharpoons$ amperes Ic $\approx$ amperes

BB.2.12.95 10.3 .15

$B B 12.12 .9510 .3 .15 .1$

$B B .2 .12 .9510 .3 .15 .2$
SCROLL screens until message screen reads "UPS OPERATING NORMALLY".

OPEN feeder circuit breaker at Standby Panelboard No. 1. Verify "AC Input Failure" LED is ILLUMINATED.

RECORD run time left on battery and 1 ink voltage:

Run Time Remaining 9 H 6 H 7 s

Link Voltage 23.5 .0 volts DC 
$8 B 12.12 .9510 .3 .15 .3$

10.3 .16

$B B+2.19 .95$ 10.3.16.1

$B_{B}(2-12.9510 .3 \cdot 16.2$

$88.12 .12 .9510 .3 \cdot 16.3$

BB.12.12.95 10.3.16.4

20.12 .12 .9510 .3 .16 .5

10.3 .17

$3312 \cdot 19.9510 .3 \cdot 1 \cdot 7.1$

$B B-12-12.9510 \cdot 3 \cdot 17.2$

$3812 \cdot 12.9510 .3 \cdot 17.3$

10.3 .18

8312.12 .9510 .3 .18 .1

$8812 \cdot 12.9510 .3 .18 .2$
CLOSE feeder circuit breaker at Standby Panelboard No. 1. Verify "AC Input Failure" LED is NOT ILLUMINATED. Verify screen reads "UPS OPERATING NORMALLY" and the "UPS Norma1" LED is ILLUMINATED.

The following Steps will verify that the diesel engine starting battery charger operates correctly:

Temporany power cowected to the ber

GLose Cireutt Breakor No. II in Panetboard UPS-PP-15-that-feeds the battery charger.

CLOSE the charger DC circuit breaker. CLOSE the charger AC circuit breaker. Charger will take up to 30 seconds to start.

Verify the AC ON light is ILLUMINATED.

RECORD system voltage from voltmeter: 27.8 DC volts. If voltage IS NOT nominal $24 \mathrm{~V}$ dc switch the voltage control switch to AUTO and charge the batteries until a nominal $24 \mathrm{Vdc}$ is
reached.

OPEN the charger AC circuit breaker. OPEN the charger DC circuit breaker. OPEN UPS-PP-15 circuit breaker no. 11.

The following steps will verify that the diesel engine jacket water heater operates as intended when engine is cold:

Jempanany power cowected to Te-006 CtOSE-Gircuit Breaker-No. 17-in-Panelboard UPS-PP-15-that foeds the jacket water heater.

RECORD output voltage and amperage at Circuit Breaker No. 17: $119.8 \mathrm{AC}$ volts $25 \mathrm{AC}$ amperes (should be approximately 25A) OPEN UPS-PP-15 Circuit Breaker No. 17.

The following steps will shut down the system:

SCROLL screens by using the "Next" pushbutton until the screen reads "UPS MAINTENANCE MENU". Press the "Enter" pushbutton. Screen will read "ENTER PASSWORD".

Depress the "Up" pushbutton until the digit "4" appears on the screen. Depress the "Next" pushbutton to activate the second digit and depress the "Up" or "Down" pushbuttons unt il the digit "F" appears on the screen. Depress the "Next" pushbutton to activate the third digit and depress the "Up" or "Down" pushbuttons until the digit " 0 " appears on the screen. Depress the "Next" pushbutton to activate the fourth digit and depress the "Up" or "Down" pushbuttons until the digit "0" appears on the screen. 
BR. $12 \cdot 12.9510 .3 \cdot 18.3$

$33.12 .12 .95-10.3 .18 .4$

$B B \dot{12.12 .95} 10.3 .18 .5$

38.12 .19 .9510 .3 .18 .6

$B B \cdot 2.12 .9510 .3 .18 .7$

$B B+12.12 .9510 .3 .18 .8$

$3 B+2.12 .9510 .3 \cdot 18.9$

$B B 12.12 .9510 .3 .18 .10$

$38.12 \cdot 12.95-10.3 \cdot 18.11$

$B B \cdot 12.12 .9510 .3 .18 .12$
Depress the "Enter" pushbutton to bring up the first of the secondary menus. Depress the "Next" or "Previous" pushbuttons to advance to the SBS Maintenance Menu and depress the "Enter" pushbutton. Depress the "Up" pushbutton to begin the Bypass/ Shutdown Procedure. The message screen will show "Confirm", depress the "Up" pushbutton for Yes.

Verify the message screen reads "CLOSE BYPASS BREAKER". CLOSE the bypass circuit breaker (CB2).

Verify the message screen reads "OPEN OUTPUT BREAKER". OPEN UPS inverter output switch (S1).

Verify the message screen reads "OPEN SBS OUTPGT TE-OOS the static bypass output switch (S2).

Verify the message screen reads "OPEN BATTERY BREAKER". OPEN the battery circuit breaker (CB3).

Verify the message screen reads "OPEN INPUT BREAKER". OPEN input circuit breaker (CBI). When the link voltage has decreased to the proper value verify the message screen reads "WAITING DC LINK = $X X X . X$ Vdc. XXX.X represents the actual voltage as displayed.

Verify the message screen reads "BYPASS/SHUTDOWN COMPLETE". Rotate UPS control switch counterclockwise to the "OFF" position. OPEN the bypass circuit breaker (CB2).

OPEN féeder circuit breaker to Automatic Transfer Switch No. 3 at Standby Panelboard No. 1.

OPEN the normal power feeder circuit breaker to ATS 1 at PP-1.

OPEN the normal power feeder circuit breaker to ATS 2 at PP-2. 
EXCEPTION NO. 001 Wo 30

Ficersad by

$$
\text { TiG.towell }
$$

SWa Na Requirsment

9.1 .19 .3 of 9.1 .19 .5

Deceription of Problem

:... sieps wene ivcomplete. $\left|\begin{array}{l}\text { ATP Na } \\ W / C-5 D-W 030-A T P-007\end{array}\right|$ Rav.

\begin{tabular}{|c|c|c|}
\hline & $\begin{array}{r}\text { Dow Rosorded } \\
12 / 11\end{array}$ & $\begin{array}{r}\text { ATP PAS No. } \\
18\end{array}$ \\
\hline
\end{tabular}

Aboue wording was adoled to steds 9.1 .193 and 9.1 .195

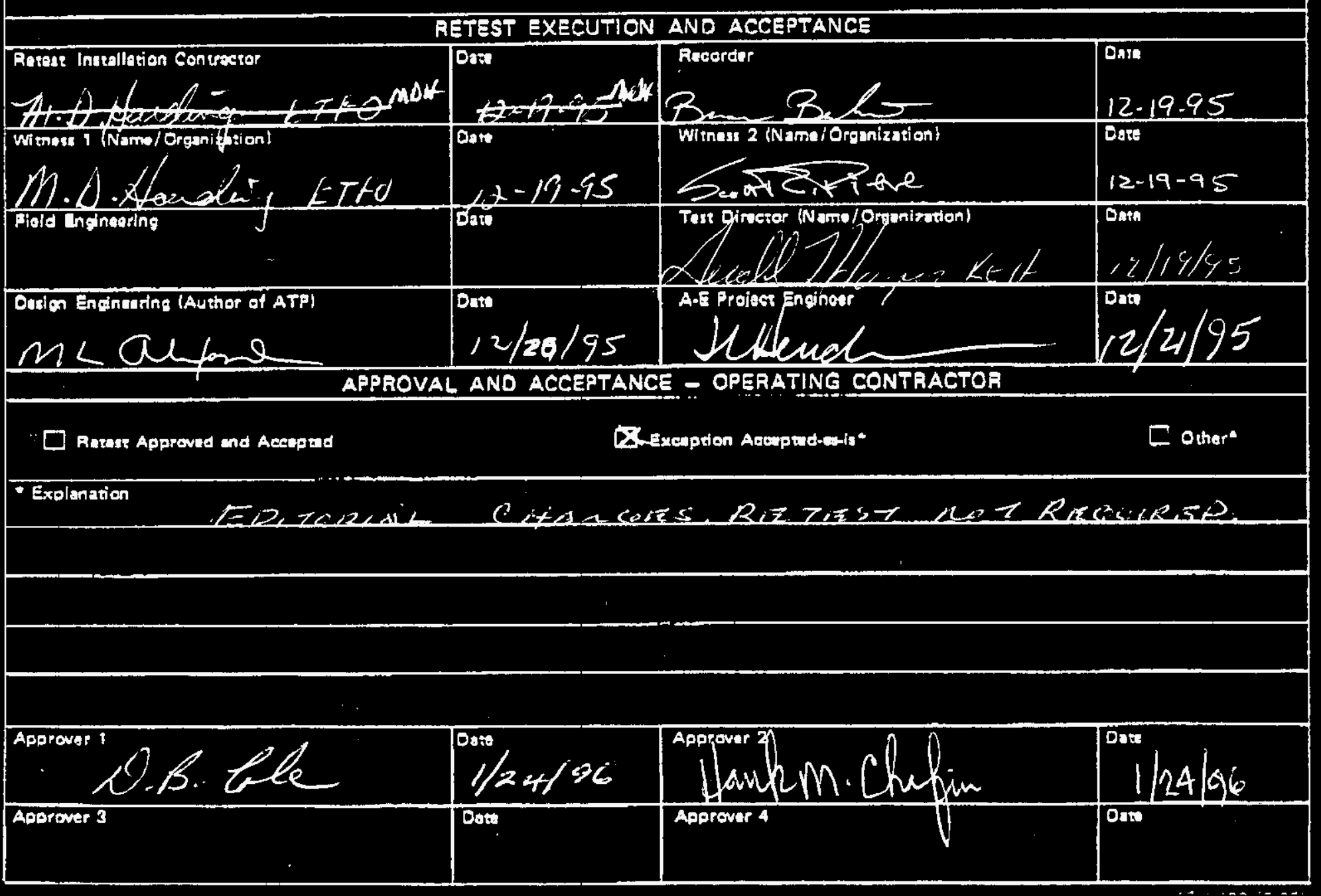




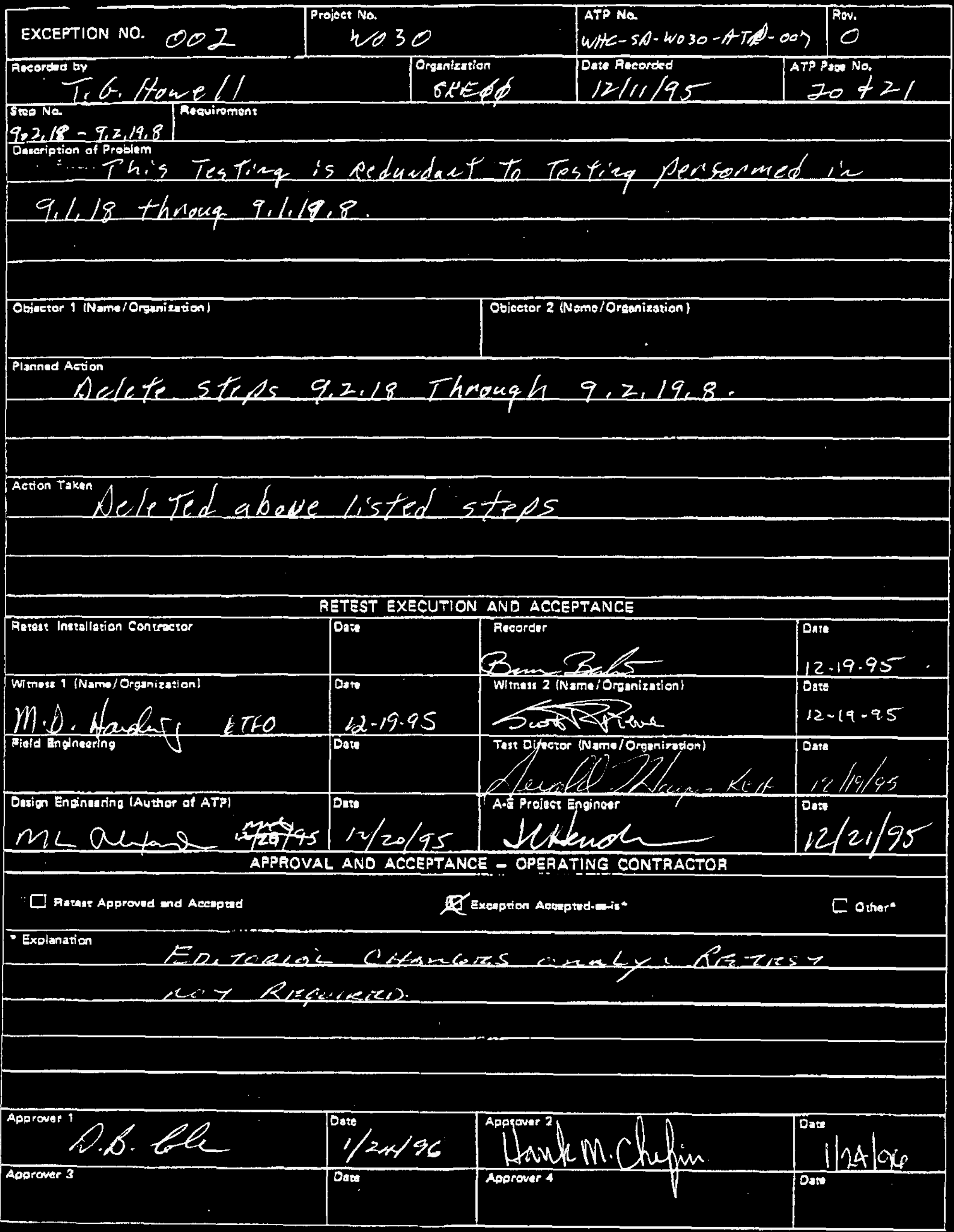




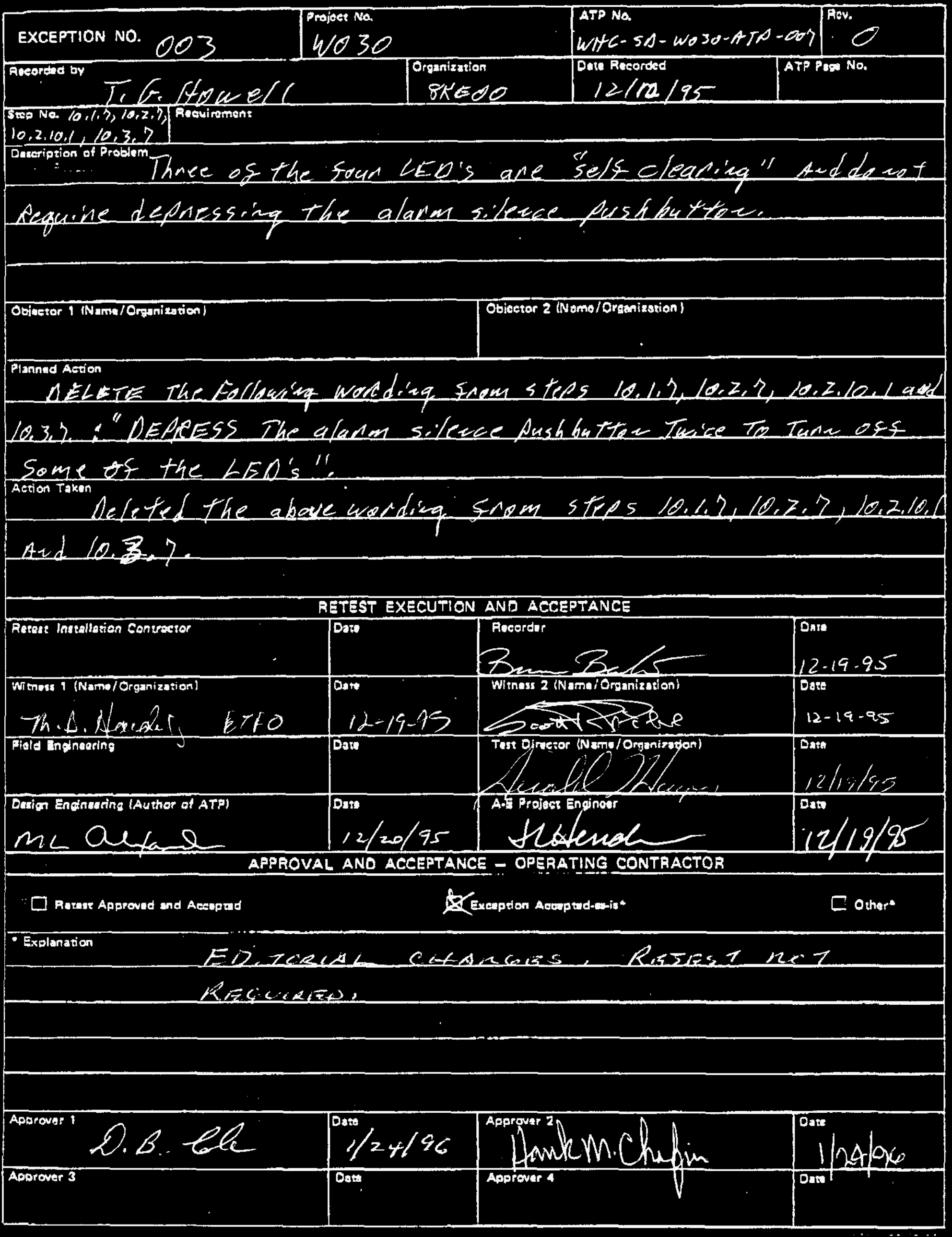


EXCEPTION NO. OOC $\quad$\begin{tabular}{l|l} 
Propeer No. \\
W0.30
\end{tabular} Ficorded by Tif. Howell
ATP Na.

ATP Pag No. $24,22,31$

3ro No $10,1.81$, Requiroment

$10,2,81,10.3,81$

Deceription of Problem

ReTrawfen Inhibited KED does vot illumivate in thi's sequence by design

Oblustor 1 (Nama/Oreanization)

Objector 2 (Nomo/Organization)

Plannid Aetion

Deley Warding ace "Aud Aefrawsen Inhibited"l

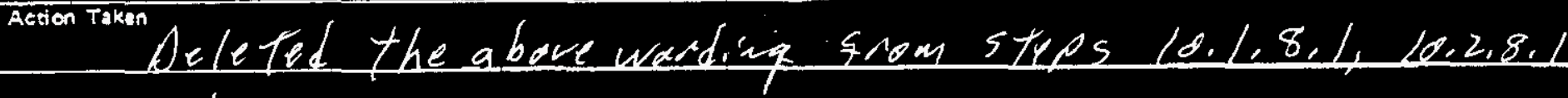
and $10,3,8,1$

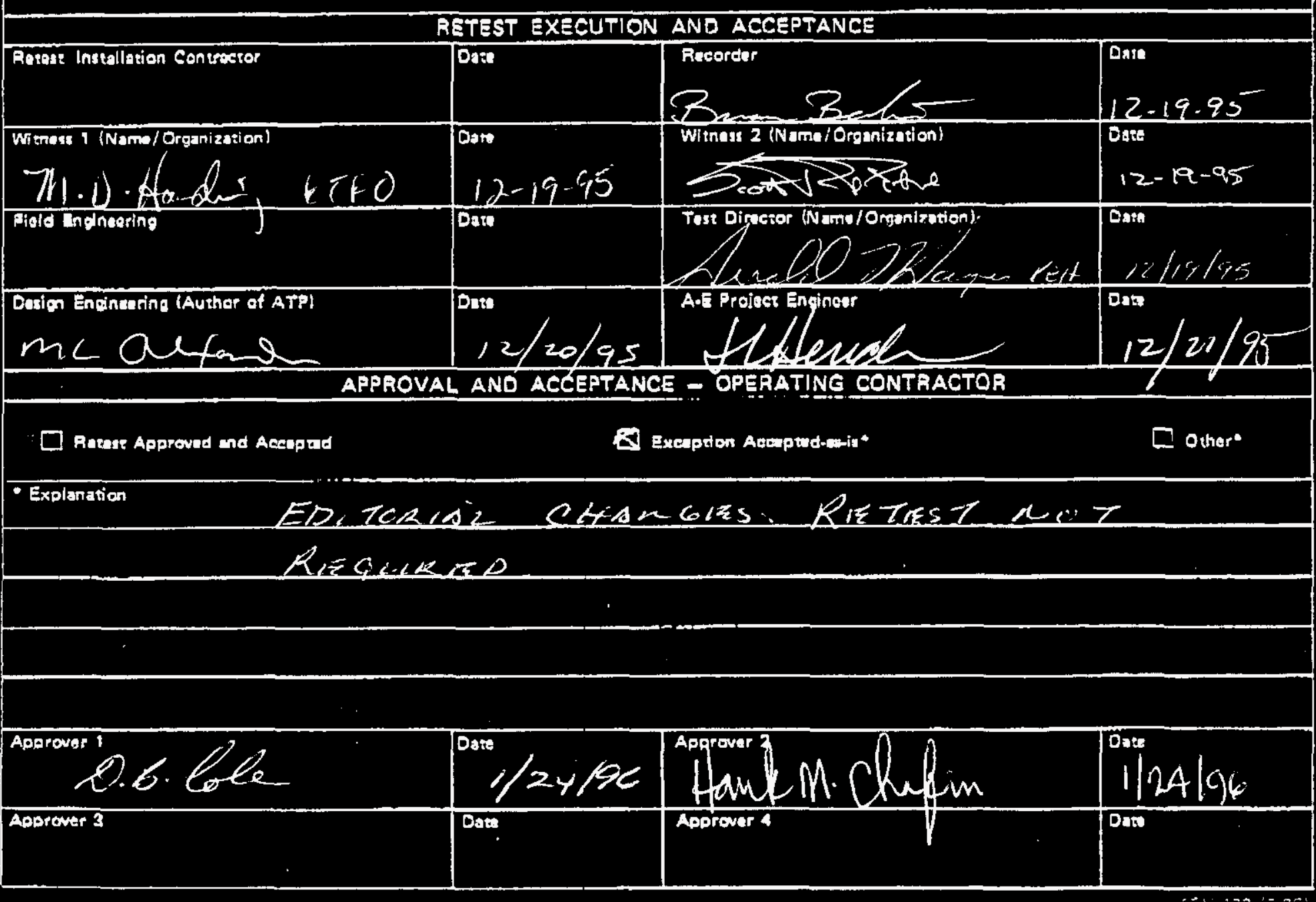




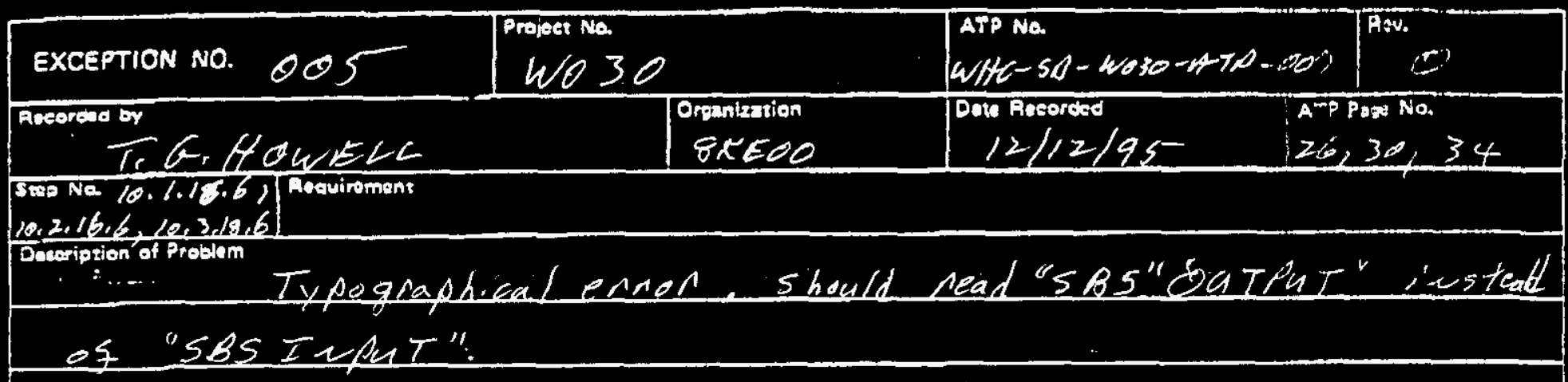

Objacter 1 Nemei Oraniestion

Obiecter 2 (Nomo/Oramizstion)

Plenned Action

Changewarding to Pead "SBS ouTPuT"

Action Taken

Chaved a bove woddrig it sty, $5,10,1,16,6,10,2,16,6$, And 10.3 .18 .6 .

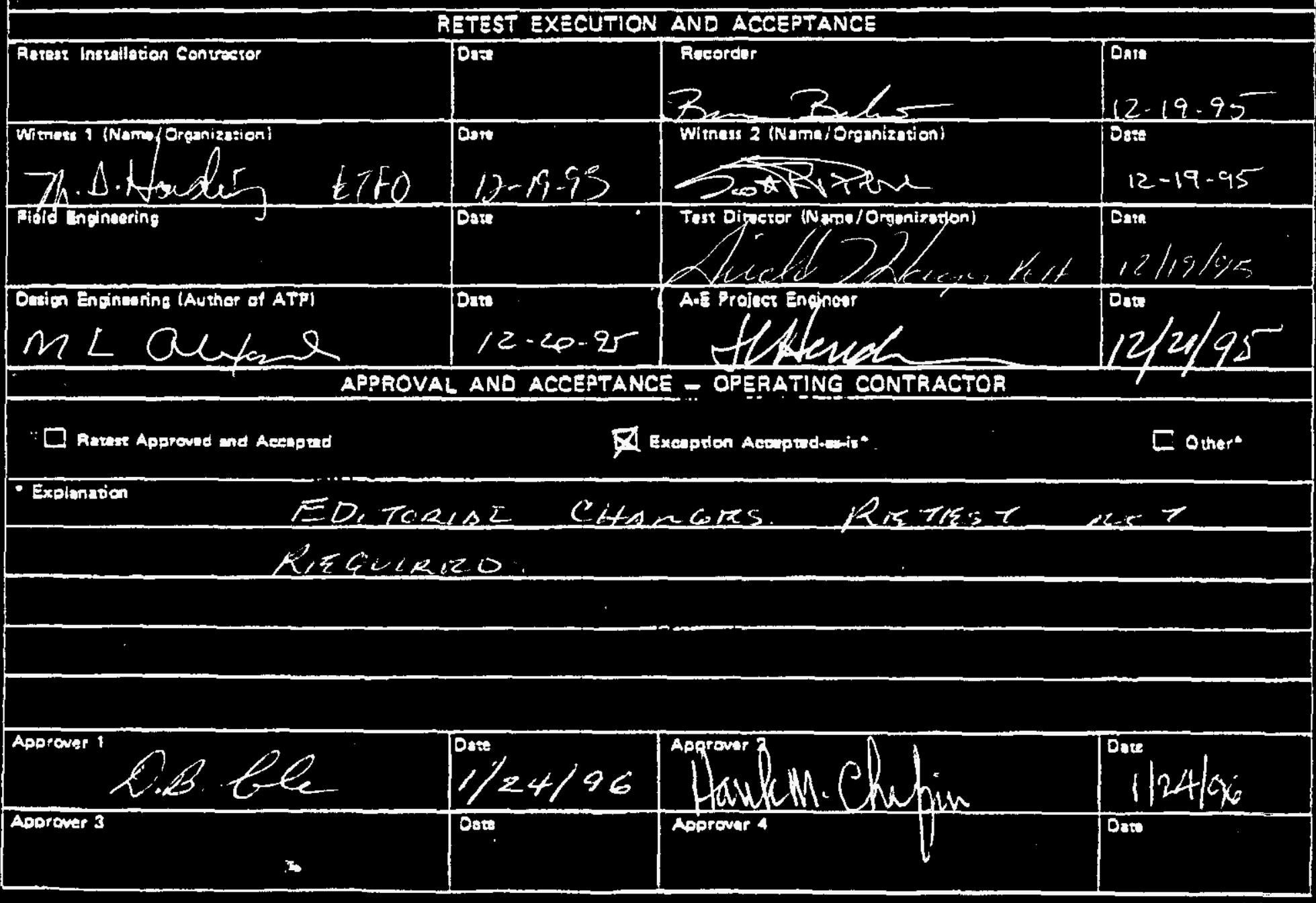




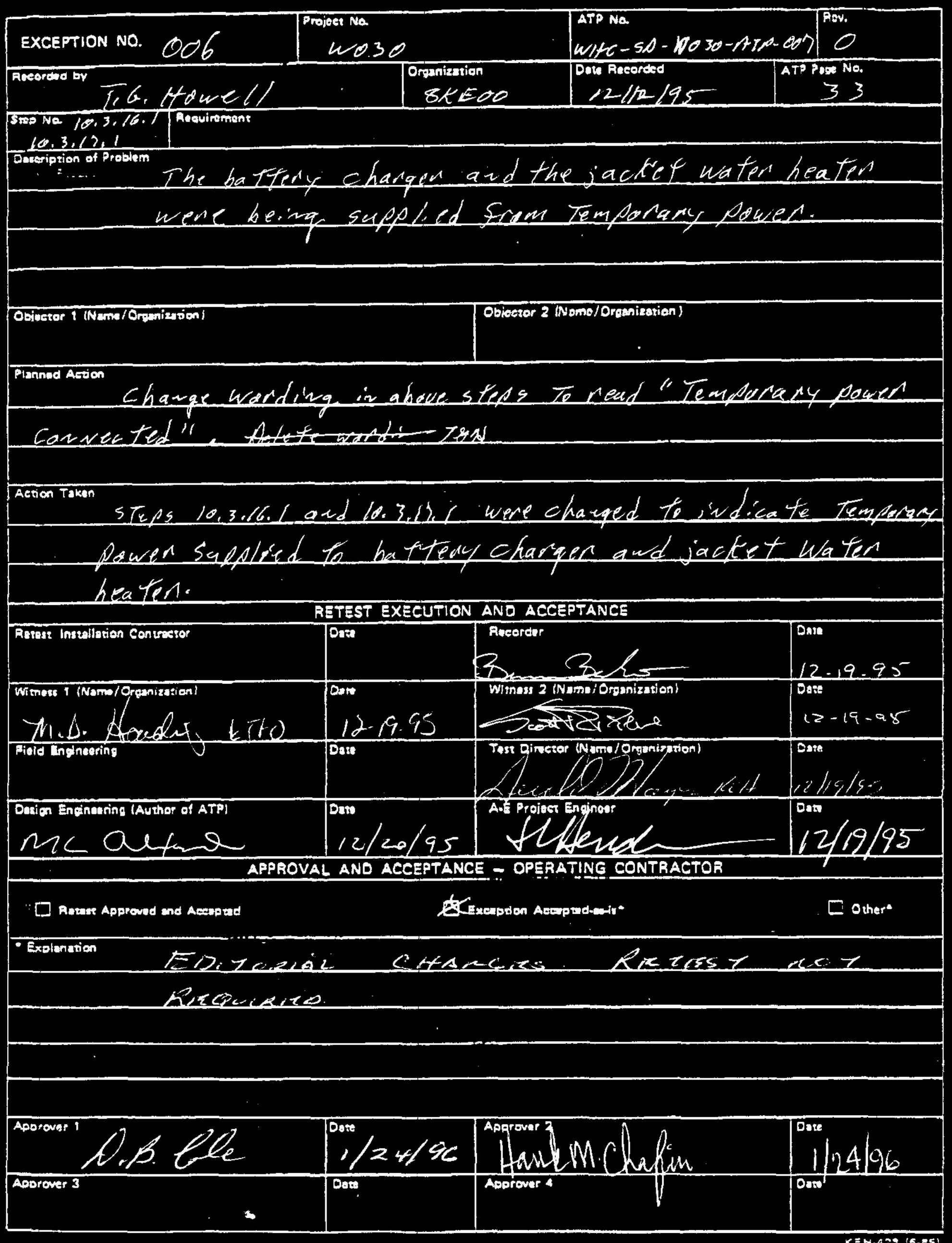




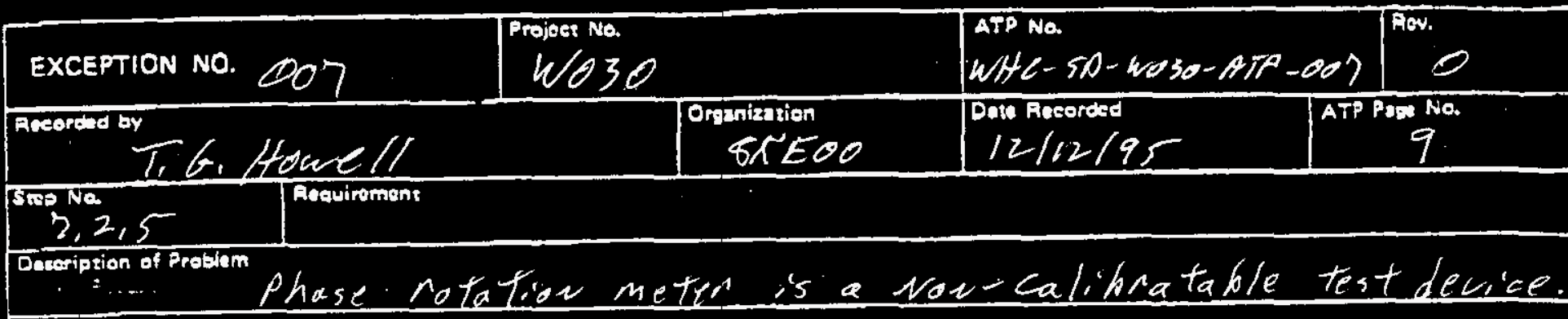

Objocter 1 (Name Toreanization)

Objector 2 (Namo/Organization)

Planncod Action

$$
\begin{aligned}
& \text { Delete spaces provided fol zustaumert Number and } \\
& \text { Expination Date }
\end{aligned}
$$

Deleted abour listed sidaces sen step $2,2.5$.

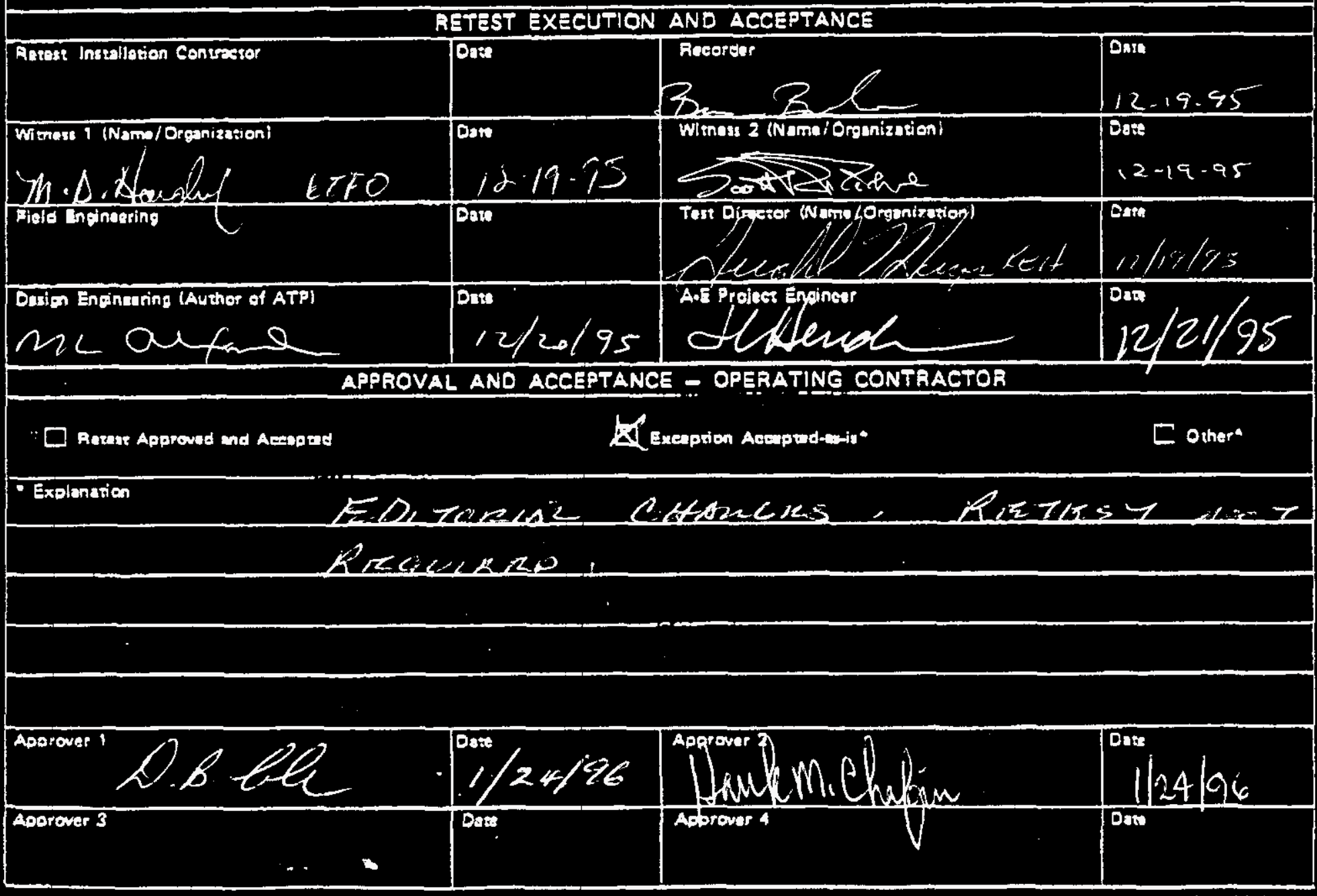




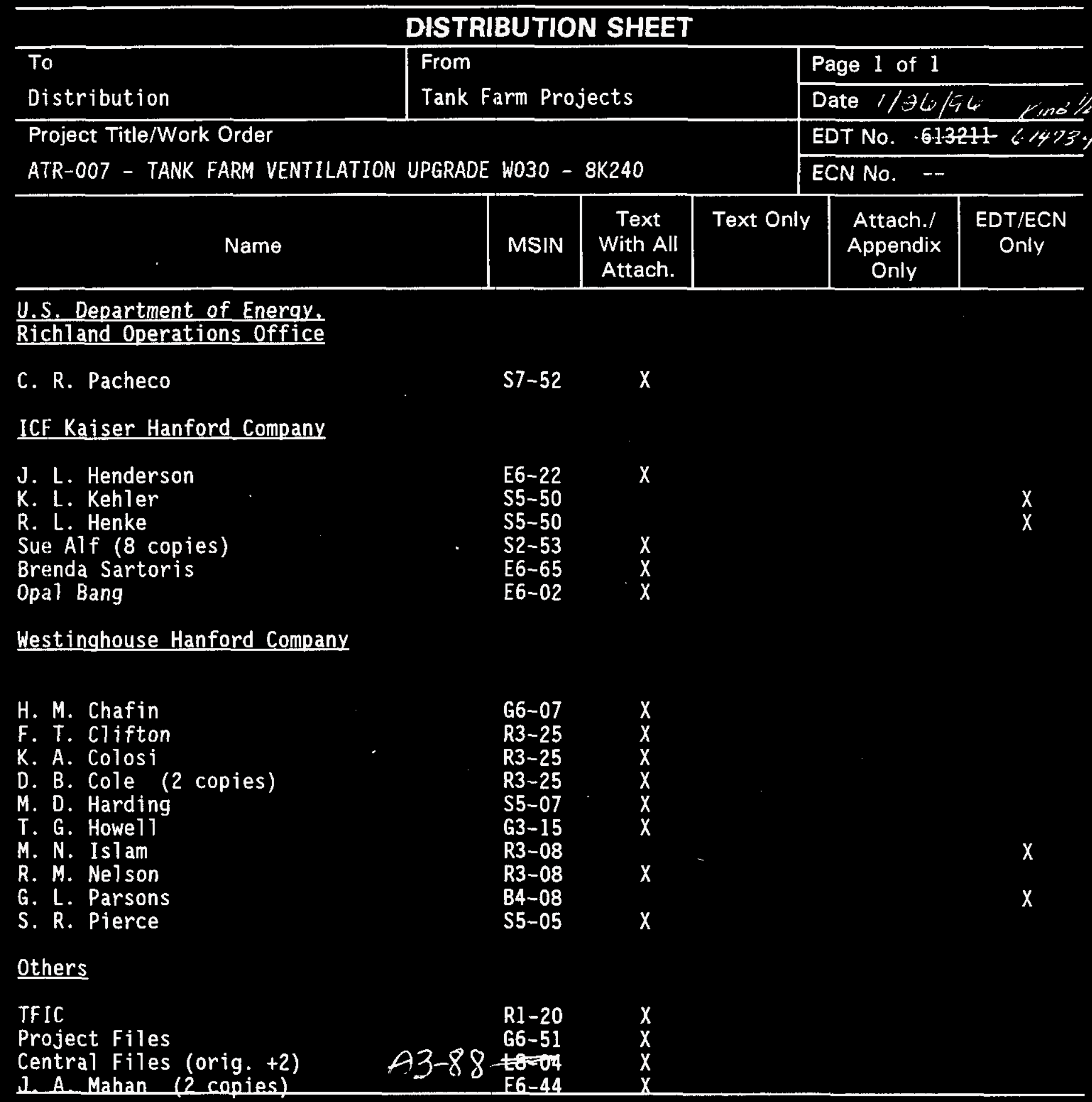

NOTE: Recipients should notify the author if copies of future similar reports are not desired, or if other changes to this distribution are needed. 